Sādhanā Vol. 40, Part 7, October 2015, pp. 2045-2072. (C) Indian Academy of Sciences

\title{
Computationally efficient models for simulation of non-ideal DC-DC converters operating in continuous and discontinuous conduction modes
}

\author{
CHALLA MOHANA KRISHNA*, SARITHA B and \\ NARAYANAN G
}

Department of Electrical Engineering, Indian Institute of Science Bangalore, Bangalore 560012, India

e-mail: mohankrishnachalla@gmail.com

MS received 30 September 2014; revised 9 April 2015; accepted 19 July 2015

\begin{abstract}
This paper discusses dynamic modeling of non-isolated DC-DC converters (buck, boost and buck-boost) under continuous and discontinuous modes of operation. Three types of models are presented for each converter, namely, switching model, average model and harmonic model. These models include significant nonidealities of the converters. The switching model gives the instantaneous currents and voltages of the converter. The average model provides the ripple-free currents and voltages, averaged over a switching cycle. The harmonic model gives the peak to peak values of ripple in currents and voltages. The validity of all these models is established by comparing the simulation results with the experimental results from laboratory prototypes, at different steady state and transient conditions. Simulation based on a combination of average and harmonic models is shown to provide all relevant information as obtained from the switching model, while consuming less computation time than the latter.
\end{abstract}

Keywords. Average model; buck converter; boost converter; buck-boost converter; harmonic model; switching model.

\section{Introduction}

DC-DC converters are an integral part of many modern electrical applications such as electric/hybrid electric vehicles (Khan 1994; Bellur et al 2007) and on-board ship power systems (Zahedi \& Norum 2013). To ensure good performance of such complex electrical system, various electrical components of the system are to be designed, controlled and integrated appropriately. Modeling and simulation of various components help to minimize the time and cost of development of the individual sub-systems as well as the overall system (Williamson et al 2006; Emadi et al 2006).

${ }^{*}$ For correspondence 
Both off-line and real-time simulation can be used to analyze the feasibility, stability and performance of the electrical system. However, off-line simulation is a priori to real-time simulation. In this paper, the models of various non-ideal converters are analyzed under off-line simulation environment. Conventionally, non-idealities of the converters are ignored during modeling (Fang 2011). This paper discusses the development of the average, harmonic and switching models of the non-isolated non-ideal DC-DC converters (Buck, Boost and Buck-Boost).

In an electric vehicle, the DC-DC converters are operated at high switching frequencies to reduce the rating and size of the passive components (Waffler \& Kolar 2009). To simulate a switching model of the converter, the time step for the simulation must be very small compared to the switching period of the active switches in the converter. Reducing the simulation time step increases the computation time and the memory resource consumption (Patil et al 2009).

Averaging techniques, discussed in literature (Pedicini et al 2012; Krein et al 1989; Sanders et al 1990; Lehman \& Bass 1994; Ren et al 2000; Jalla et al 2004; Chung et al 2009), include state-space and switching cycle averaging methods. State-space averaging technique is a matrix based technique, increasing the computational effort (Vuthchhay \& Bunlaksananusorn 2008). Hence the switching-cycle-averaged model is used in this paper.

Average models of dc-dc converters yield the voltages and currents of the converter, averaged over each switching cycle. The simulated voltage and current waveforms contain only the $\mathrm{dc}$ and low-frequency components, and not the switching-frequency ripple. Prediction of such switching-cycle-averaged waveforms is sufficient in many practical situations. More importantly, simulation with such an average model consumes much less time than the switching model since the time step could be much longer than in case of a switching model.

Most average models of $\mathrm{dc}-\mathrm{dc}$ converters are valid for converter operation with moderate to heavy loads, when the converter is operating in the so-called continuous conduction mode (CCM) (Merdassi et al 2008). A few models pertain only to light load conditions or the so-called discontinuous conduction mode (DCM) (Hwang \& Park 2012). The models presented in this paper can predict the operation of the converter under heavy loads (i.e. CCM), light loads (i.e. DCM) and also during transition between light and heavy loads.

While prediction of average voltages and currents is sufficient under many scenarios, ripple quantities are also important for the converter design. The ripple on output voltage, for example, is an important design specification, indicating the quality of the converter output (Mohan et al 2007). The sizing of the filter components depend on the maximum allowable ripple currents and voltages in the converter (Badstuebner et al 2010). Further, the ripple quantities also determine or influence the losses in various components. Hence this paper presents the harmonic model for each of the dc-dc converters to evaluate the peak-to-peak voltage and current ripples, based on certain average voltages and currents in the converter. It is shown that a combination of average model and harmonic model, termed here as combined model, can give all the essential information that are available from the switching model.

The authors presented the preliminary results pertaining to the non-ideal boost converter in the National Power Electronics Conference (NPEC) (Saritha et al 2013). This paper presents and evaluates the switching model, average model, harmonic model and combined model for non-ideal buck, boost and buck-boost converters, in detail. The models are evaluated in terms of accuracy and computational effort. The accuracy of the models is verified by comparing the simulation results with the experimental data from $20 \mathrm{~W}$ laboratory prototype converters. The models are compared in terms of computational time required for simulation of the converters in MATLAB environment. 


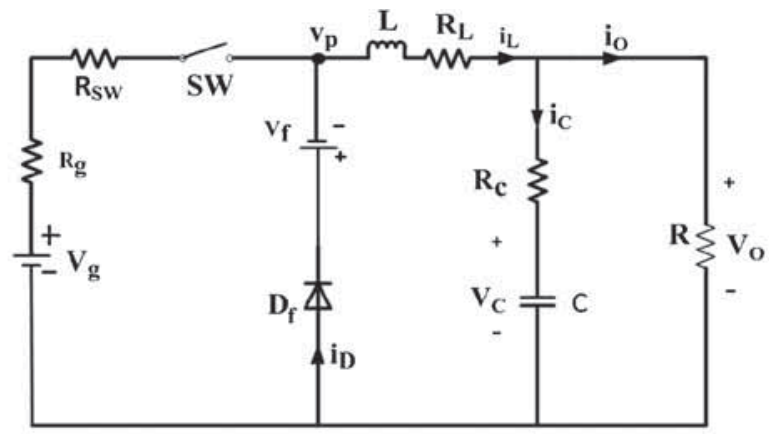

(a)

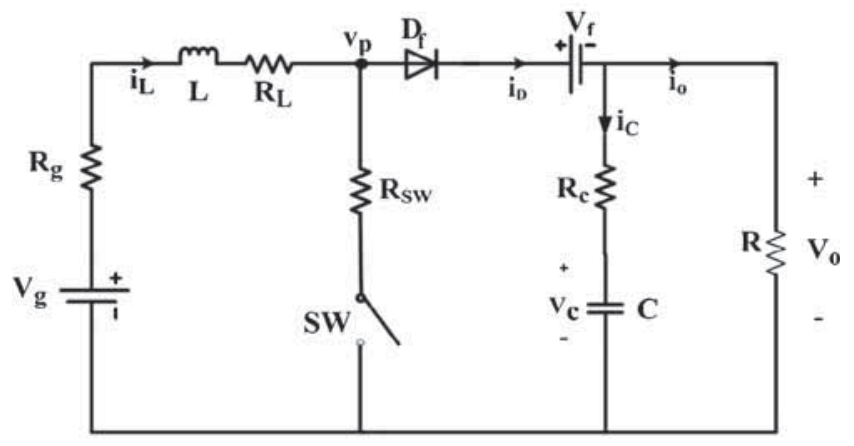

(b)

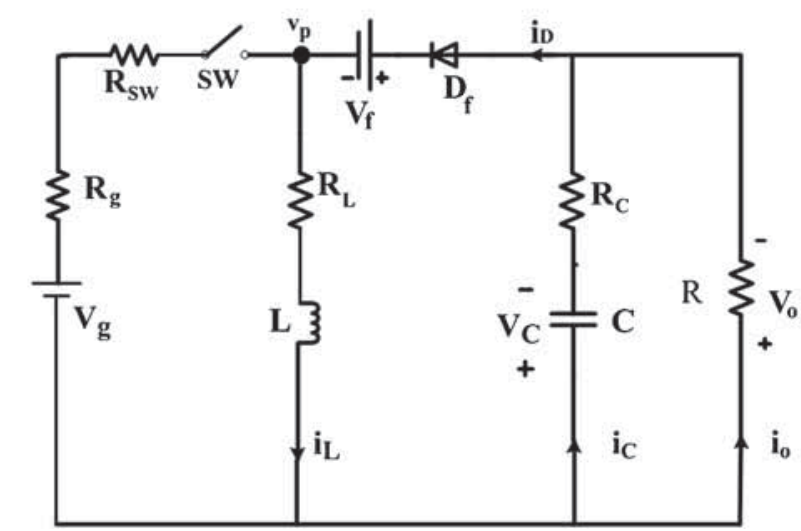

(c)

Figure 1. Circuit schematic of non-ideal (a) buck converter (b) boost converter (c) buck-boost converter.

\section{Approach to modeling of non-ideal DC-DC converterss}

A buck converter, a boost converter and a buck-boost converter having significant non-idealities are shown schematically in figures 1(a), 1(b) and 1(c), respectively. There are both similarities and dissimilarities among the three converters. This section presents an approach to modeling of non-ideal dc-dc converters. 


\subsection{Non-idealities}

The non-ideal voltage source (or the output of the previous power conversion stage) is denoted by a voltage source with an open-circuit voltage $V_{\mathrm{g}}$ and an internal resistance $R_{\mathrm{g}}$. Each nonideal active and passive element in the converter is represented by an ideal element in series with a resistance, which is a quantitative representation of the non-ideality. The actual MOSFET is represented as an ideal switch SW in series with the on-state drain-to-source resistance $R_{\mathrm{SW}}$, and the diode is considered as an ideal diode $D_{\mathrm{f}}$ in series with a forward voltage drop $V_{\mathrm{f}}$. The practical inductor is represented as a series combination of inductance $\mathrm{L}$ and resistance $R_{\mathrm{L}}$. The non-ideal capacitor is regarded as a combination of an ideal capacitor $\mathrm{C}$ with an equivalent series resistance $R_{\mathrm{C}}$. The load or the next power conversion stage is modeled as a resistance $\mathrm{R}$.

For simulation and experimental validation of the models of the three converters, the converter parameters considered are as shown in table 1. Both the values of the ideal elements and also their respective non-idealities in the three converters are tabulated in table 1.

\subsection{Switching functions}

The status of the ideal switch SW and that of the diode $D_{\mathrm{f}}$ are given by the switching functions $S_{1}$ and $S_{2}$, respectively. The switching function is either 1 or 0 , depending on whether the device is ON or OFF. The switching function $S_{1}$ is supplied by the controller, and $S_{2}$ is generated by the converter model. The average values of $S_{1}$ and $S_{2}$ over a switching cycle are the duty ratio of MOSFET (i.e. $D_{1}$ ) and that of diode (i.e. $D_{2}$ ), respectively. Similar to $S_{1}$ and $S_{2}$, the duty ratio $D_{1}$ is an input to the converter model, and $D_{2}$ is generated internally by the model.

\subsection{Conduction modes}

In all the three dc-dc converters, energy gets stored into the inductor during the ON-time of the active switch (MOSFET). The energy stored at the end of the ON-time causes freewheeling of the inductor current through the diode. If the energy stored is high enough, then the freewheeling action or conduction through the inductor continues throughout the OFF-time of the active switch, as illustrated in figure 2(a). This is termed as continuous conduction mode (CCM). On the other hand, if the energy stored is inadequate, the current conduction through the inductor and diode stops midway through the OFF-time of the active switch, as shown in figure 2(b). This is termed as discontinuous conduction mode (DCM). During the ON-time of MOSFET, the switching functions are $S_{1}=1$ and $S_{2}=0$. When the freewheeling diode is ON, the switching functions are $S_{1}=0$ and $S_{2}=1$. In case of DCM, when both the MOSFET and diode are OFF, the switching functions are $S_{1}=0$ and $S_{2}=0$.

Table 1. Value of the various components in dc-dc converter.

\begin{tabular}{lccc}
\hline Components of the converter & Buck converter & Boost converter & Buck-Boost converter \\
\hline Inductor $(\mathrm{L})$ & $12.5 \mathrm{mH}$ & $2 \mathrm{mH}$ & $2.5 \mathrm{mH}$ \\
Capacitor $(\mathrm{C})$ & $22 \mu \mathrm{F}$ & $11 \mu \mathrm{F}$ & $10 \mu \mathrm{F}$ \\
Load (R) & $25 \Omega$ & $100 \Omega$ & $222 \Omega$ \\
Drop across diode $\left(V_{\mathrm{f}}\right)$ & $0.8 \mathrm{~V}$ & $0.8 \mathrm{~V}$ & $0.8 \mathrm{~V}$ \\
ON resistance of switch $\left(R_{\text {sw }}\right)$ & $55 \mathrm{~m} \Omega$ & $55 \mathrm{~m} \Omega$ & $55 \mathrm{~m} \Omega$ \\
Resistance of inductor $\left(R_{\mathrm{l}}\right)$ & $2.5 \Omega$ & $2 \Omega$ & $3.5 \Omega$ \\
Series resistance of capacitor $\left(R_{\mathrm{c}}\right)$ & $1.5 \Omega$ & $3 \Omega$ & $0.61 \Omega$ \\
Source resistance $\left(R_{\text {in }}\right)$ & $1 \mathrm{~m} \Omega$ & $1 \mathrm{~m} \Omega$ & $1 \mathrm{~m} \Omega$ \\
\hline
\end{tabular}




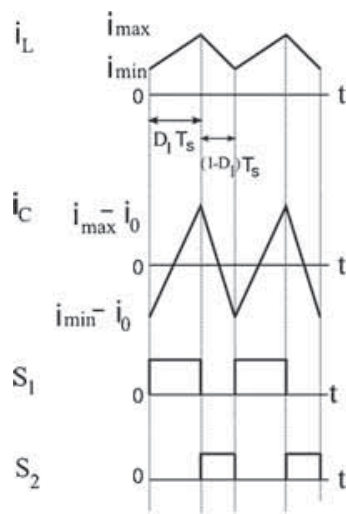

(a)

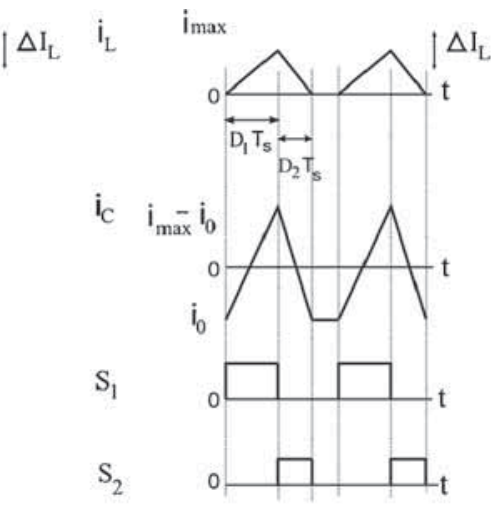

(b)

Figure 2. Inductor current under (a) CCM (b) DCM.

\subsection{Pole voltage}

The common node between the active device and the diode is termed as pole. Each of the three converters can be seen as a second-order system, driven by the pole voltage $\left(v_{\mathrm{p}}\right)$ as an input. It is straightforward to express the pole voltage in terms of the input voltage $V_{\mathrm{g}}$ and switching functions in an ideal dc-dc converter. This paper presents a generalized pole voltage expression for each converter, valid for both CCM and DCM, and inclusive of the effects of non-idealities.

\subsection{Inductor current}

The voltage at one terminal of the inductor L in a DC-DC converter (buck or boost or buckboost) is fixed. This may be the input voltage, the output voltage or the reference zero. Hence the inductor current is controlled by the pole voltage $v_{\mathrm{p}}$, which is applied at the other terminal of the inductor. Essentially, the difference between the pole voltage on one terminal and the fixed voltage on the other terminal, is integrated to calculate inductor current $i_{\mathrm{L}}$.

\subsection{Output voltage}

The capacitor current $i_{\mathrm{C}}$ is essentially the ripple component of the inductor current $i_{\mathrm{L}}$ (in case of buck converter) or that of the diode current $i_{\mathrm{D}}$ (in case of boost and buck-boost converters). In the latter case, the diode current $i_{\mathrm{D}}$ is obtained by multiplying the inductor current $i_{\mathrm{L}}$ with the switching function $S_{2}$. The load current $i_{0}$ is subtracted from $i_{\mathrm{L}}$ or $i_{\mathrm{D}}$, to determine its ripple component i.e. $i_{\mathrm{C}}$. The capacitor voltage $v_{\mathrm{c}}$ is obtained by integration of the capacitor current $i_{\mathrm{C}}$. The output voltage $v_{0}$ is the sum of capacitor voltage $v_{\mathrm{c}}$ and the voltage drop across the equivalent series resistance (ESR) of the capacitor $R_{\mathrm{C}}$.

\subsection{Types of dynamic models}

The modeling approach, discussed so far, is represented by the block diagrams in figure 3 . Dynamic modeling of a converter can provide either the instantaneous values (switching model) 


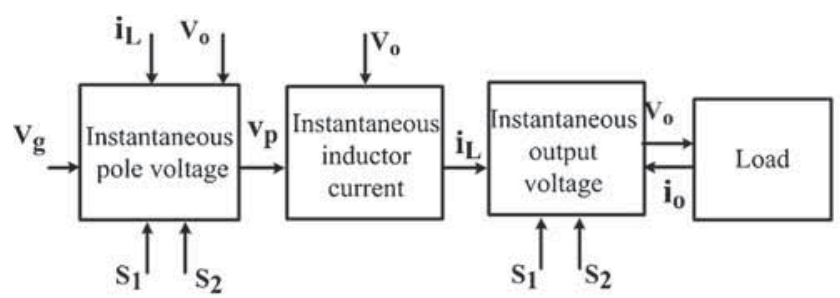

(a)

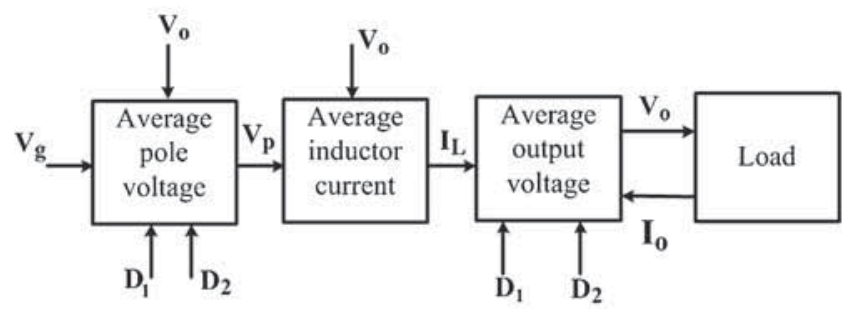

(b)

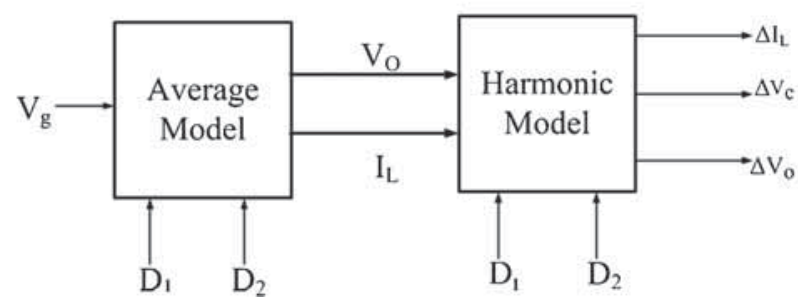

(c)

Figure 3. General representation of the models of converter (a) switching model (b) average model (c) combined average and harmonic model.

or the switching-cycle averaged values (average model) of the electrical quantities. As seen from figure 3(a), the switching model is driven by the switching functions $S_{1}$ and $S_{2}$. Using the switching functions and the input voltage, the instantaneous pole voltage $v_{\mathrm{p}}$ is generated, which is then used to evaluate the inductor current and output voltage. The average model, shown in figure $3 \mathrm{~b}$, is driven by the duty cycles $D_{1}$ and $D_{2}$. This model produces the average pole voltage $V_{\mathrm{P}}$; the average inductor current $I_{\mathrm{L}}$ and average output voltage $V_{0}$ are calculated from $V_{\mathrm{P}}$. These average quantities, along with the two duty ratios, are used by the harmonic model to evaluate the peak-to-peak ripple in inductor current $\left(\Delta I_{\mathrm{L}}\right)$ and that in output voltage $\left(\Delta V_{\mathrm{o}}\right)$, as shown by figure 3(c). The average model and the harmonic model in cascade, as shown by figure 3(c), are termed as the combined model, in this paper.

\section{Switching model}

The switching models of the buck, boost and buck-boost converters are shown by figures 4(a), 4(b) and 4(c), respectively. These switching models can mimic the behavior of the converters under CCM as well as DCM. The switching function $S_{1}$ of an ideal switch SW is supplied by the 

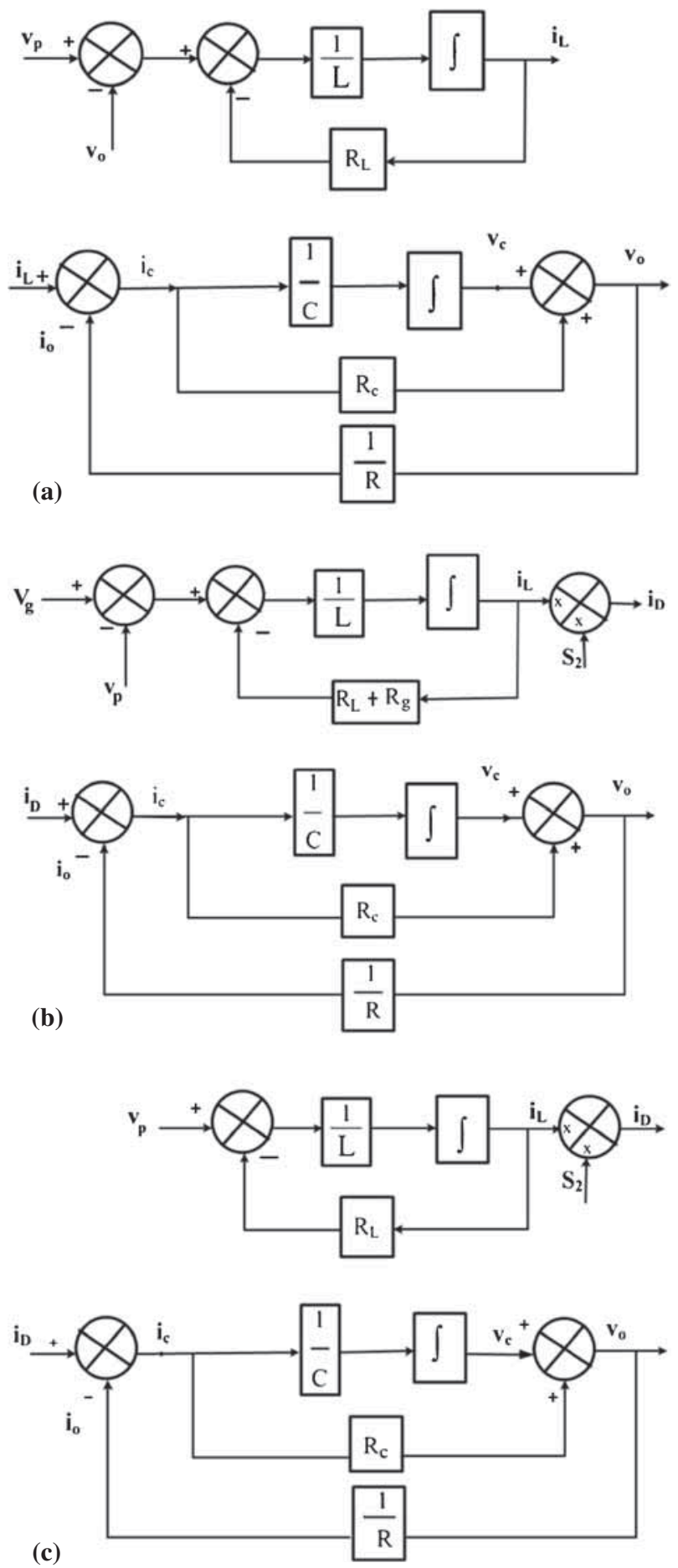

Figure 4. Block diagram representation of the model of (a) buck converter (b) boost converter (c) buck-boost converter. 
Table 2. Expression for instantaneous pole voltage $v_{\mathrm{p}}$ for different converters.

\begin{tabular}{lll}
\hline Converter & Mode & \multicolumn{1}{c}{ Voltage $v_{\mathrm{p}}$} \\
\hline Buck & CCM & $\left(\mathrm{v}_{\mathrm{g}}-\mathrm{i}_{\mathrm{L}} \mathrm{R}_{\mathrm{g}}-\mathrm{R}_{\mathrm{L}} \mathrm{i}_{\mathrm{L}}\right) \mathrm{S}_{1}-\left(\mathrm{V}_{\mathrm{f}}\right) \mathrm{S}_{2}$ \\
& DCM & $\left(\mathrm{v}_{\mathrm{g}}-\mathrm{i}_{\mathrm{L}} \mathrm{R}_{\mathrm{g}}-\mathrm{R}_{\mathrm{L}} \mathrm{i}_{\mathrm{L}}\right) \mathrm{S}_{1} \overline{\mathrm{S}_{2}}-\left(\mathrm{V}_{\mathrm{f}}\right) \overline{\mathrm{S}_{1}} \mathrm{~S}_{2}+\mathrm{V}_{\mathrm{o}} \overline{\mathrm{S}_{1}} \overline{\mathrm{S}_{2}}$ \\
Boost & CCM & $\mathrm{i}_{\mathrm{L}} \mathrm{R}_{\mathrm{sw}} \mathrm{S}_{1}+\left(\mathrm{v}_{\mathrm{o}}+\mathrm{V}_{\mathrm{f}}\right) \mathrm{S}_{2}$ \\
& DCM & $\mathrm{i}_{\mathrm{L}} \mathrm{R}_{\mathrm{sw}} \mathrm{S}_{1} \overline{\mathrm{S}_{2}}+\left(\mathrm{v}_{\mathrm{o}}+\mathrm{V}_{\mathrm{f}}\right) \overline{\mathrm{S}_{1}} \mathrm{~S}_{2}+\mathrm{Vg}_{\mathrm{S}} \overline{\mathrm{S}_{2}}$ \\
\multirow{3}{*}{ Buck-Boost } & CCM & $\left(\mathrm{V}_{\mathrm{g}}-\mathrm{i}_{\mathrm{L}} \mathrm{R}_{\mathrm{g}}-\mathrm{R}_{\mathrm{SW}} \mathrm{i}_{\mathrm{L}}\right) \mathrm{S}_{1}+\left(-\mathrm{v}_{\mathrm{o}}-\mathrm{V}_{\mathrm{f}}\right) \mathrm{S}_{2}$ \\
& DCM & $\left(\mathrm{V}_{\mathrm{g}}-\mathrm{i}_{\mathrm{L}} \mathrm{R}_{\mathrm{g}}-\mathrm{R}_{\mathrm{SW}} \mathrm{i}_{\mathrm{L}}\right) \mathrm{S}_{1} \overline{\mathrm{S}_{2}}+\left(-\mathrm{v}_{\mathrm{o}}-\mathrm{V}_{\mathrm{f}}\right) \overline{\mathrm{S}_{1}} \mathrm{~S}_{2}$ \\
\hline
\end{tabular}

controller. The function $S_{2}$ is generated within simulation program as shown by the following equation.

$$
\begin{aligned}
S_{2} & =\overline{S_{1}} \quad \text { if } i_{\mathrm{L}}>0 \\
& =0 \quad \text { if } i_{\mathrm{L}}=0 .
\end{aligned}
$$

The switching functions are used to determine the instantaneous pole voltage $v_{\mathrm{P}}$. The expressions for $v_{\mathrm{P}}$ are different for the three converters, as shown by table 2 . These equations are obtained from the respective schematic diagrams of the converters, shown in figure 1 . It can be seen that the expression for $v_{\mathrm{P}}$ under DCM is more general and is used in the simulation of a switching model. By imposing $S_{2}=\overline{S_{1}}$ on the general expression, the corresponding expression for CCM operation is obtained.

Calculation of inductor current $i_{\mathrm{L}}$ based on $v_{\mathrm{P}}$ and output voltage $v_{\mathrm{o}}$ based on $i_{\mathrm{L}}$ are illustrated by the block diagram in figure 4(a), which together with Eq. (1), define the switching model of a buck converter. In figures 4 (b) and 4(c), the inductor current $i_{\mathrm{L}}$ is multiplied by the switching function $S_{2}$ to obtain the diode current $i_{\mathrm{D}}$. The diode current $i_{\mathrm{D}}$ is then used to calculate the capacitor voltage $v_{\mathrm{c}}$ and the output voltage $v_{\mathrm{o}}$ of the boost and buck-boost converters.

\section{Average model}

Averaged model provides ripple free averaged values of various voltages and currents of the converter. The non-idealities in the converter could have significant effect on the output voltage. Expressions are derived in this section for the output voltage of the non-ideal converters. The output voltage depends not only on the duty ratio of the MOSFET, but also on that of the diode. Hence expressions are derived for the duty ratio of the diode (i.e. $D_{2}$ ) for the three converters. These are used to determine the boundary conditions for CCM and DCM operation of the converters.

\subsection{Non-ideal voltage gain}

Referring to figure 1(a), the volt-second balance across the ideal inductance $\mathrm{L}$ in a buck converter at steady state can be expressed as shown in (2). Further, this equation can be rewritten as shown in (3), where $I_{\mathrm{L}, \mathrm{ON}}$ and $I_{\mathrm{L}, \mathrm{OFF}}$ are the average values of the inductor current over the on-time and off-time, respectively, of the MOSFET switch.

$$
\int_{0}^{D_{1} T_{\mathrm{s}}}\left(V_{g}-i_{L}\left(R_{g}+R_{s w}+R_{L}\right)-V_{0}\right) \mathrm{d} t=\int_{D_{1} T_{\mathrm{s}}}^{\left(D_{1}+D_{2}\right) T_{s}}\left(V_{f}+i_{\mathrm{L}} R_{\mathrm{L}}+V_{0}\right) \mathrm{d} t
$$




$$
\begin{gathered}
\left(V_{g}-I_{L, O N}\left(R_{g}+R_{S w}+R_{L}\right)-V_{0}\right) D_{1} T_{\mathrm{S}}=\left(V_{f}+I_{L, O F F} R_{L}+V_{0}\right) D_{2} T_{\mathrm{S}} \\
I_{L, O N}=\frac{I_{p}}{2} ; I_{L, O F F} \frac{I_{p}}{2} \text { and } I_{\mathrm{p}}=\frac{2 V_{0}}{R} \frac{1}{D_{1}+D_{2}} .
\end{gathered}
$$

During the on-time of the MOSFET, the time constant $\tau_{\mathrm{ON}}=\frac{L}{\left(R_{g}+R_{S W}+R_{L}\right)}$ is much longer than the on-time of the switch i.e. $D_{1} T_{\mathrm{S}}$. Similarly, during the off-interval of the active switch, the time constant $\tau_{\mathrm{OFF}}=\frac{L}{\left(R_{L}\right)}$ is very much high, compared to $D_{2} T_{\mathrm{S}}$. Hence the inductor current can be assumed to vary linearly with time in both the intervals as shown in figure 2. Consequently, $I_{\mathrm{L}, \mathrm{ON}}$ and $I_{\mathrm{L}, \mathrm{OFF}}$ can be expressed in terms of the peak current $i_{\mathrm{P}}$ as shown in (4). The peak current is also related to the output voltage $V_{\mathrm{o}}$, as shown in (4).

Using (3) and (4), the non-ideal output voltage $V_{0}$ of the buck converter can be expressed in terms of $V_{\mathrm{g}}, D_{1}$ and $D_{2}$ as shown in table 3. A similar procedure is followed to derive the expressions for $V_{0}$ for the boost and buck-boost converters. These expressions are also tabulated in table 3. All these expressions pertain to the more general case of DCM. Replacing the variable $D_{2}$ by $\left(1-D_{1}\right)$ in these expressions yields the output voltage pertaining to CCM operation of the converters.

\subsection{Calculation of duty ratio $\mathrm{D}_{2}$}

Considering DCM, the KVL equation of the inductive circuit during the diode conduction period $D_{2} T_{\mathrm{S}}$ in a non-ideal buck converter can be written, as shown in (5). The corresponding averaged KVL equation is shown in (6). The average inductor current during the off-time of the switch $I_{\mathrm{L}, \mathrm{OFF}}$ and peak current $I_{\mathrm{p}}$ are expressed in terms of output voltage $V_{0}$, as shown in (7).

$$
\begin{gathered}
L \frac{d i_{L}}{d t}=V_{f}+V_{0}+i_{L} R_{L} \\
L \frac{I_{p}}{D_{2} T_{s}}=V_{f}+V_{0}+I_{L, O F F} R_{L} \\
L \frac{2 V_{0}}{R} \frac{1}{D_{1}+D_{2}} \frac{1}{D_{2} T_{s}}=V_{f}+V_{0}+\frac{V_{0}}{R} \frac{1}{D_{1}+D_{2}} R_{L}
\end{gathered}
$$

Substituting for the output voltage $V_{\mathrm{o}}$ in (7) by the appropriate expression from table 3, an equation is obtained, which relates $D_{1}$ and $D_{2}$ in a buck converter. This equation is

Table 3. Steady-state output voltage of the non-ideal converters.

\begin{tabular}{lc}
\hline Type & Voltage $V_{0}$ \\
\hline Buck & $\frac{V_{\mathrm{g}} D_{1}-V_{\mathrm{f}} D_{2}}{\frac{R_{\mathrm{L}}}{R}+\frac{D_{1}}{\left(D_{1}+D_{2}\right)} \frac{\left(R_{\mathrm{g}}+R_{\mathrm{SW}}\right)}{R}+D_{1}+D_{2}}$ \\
Boost & $\frac{V_{\mathrm{g}}\left(D_{2}^{2}+D_{1} D_{2}\right)-V_{\mathrm{f}} D_{2}^{2}}{\frac{\left(R_{\mathrm{g}}+R_{\mathrm{L}}+R_{\mathrm{SW}}\right)}{R} D_{1}+D_{2} \frac{\left(R_{\mathrm{g}}+R_{\mathrm{L}}\right)}{R}+D_{2}^{2}}$ \\
Buck-Boost & $-\left[\frac{V_{\mathrm{g}} D_{1}+V_{\mathrm{f}} D_{2}}{D_{2}+\frac{R_{\mathrm{L}}}{R}-\frac{D_{1}}{D_{2}}\left(\frac{R_{\mathrm{g}}+R_{\mathrm{L}}+R_{\mathrm{SW}}}{R}\right)}\right]$ \\
\hline
\end{tabular}


Table 4. Expression for $\mathrm{D}_{2}$ including non-idealities.

\begin{tabular}{ll}
\hline Converter & Expression for $D_{2}$ \\
\hline Buck & $D_{2}^{3} V_{\mathrm{f}}-D_{1} D_{2}^{2} V_{\mathrm{g}}+D_{2}\left(-K V_{\mathrm{f}}-D_{1}^{2} V_{\mathrm{g}}-2 D_{1}^{2} V_{\mathrm{f}}-\frac{R_{\mathrm{L}}}{R} D_{1} V_{\mathrm{f}}\right)$ \\
& $+\left(D_{1} V_{\mathrm{g}} K-D_{1}^{3} V_{\mathrm{f}}-D_{1}^{2} \frac{R_{\mathrm{g}}+R_{\mathrm{SW}}}{R} V_{\mathrm{f}}-\frac{R_{\mathrm{L}}}{R} D_{1}^{2} V_{\mathrm{f}}\right)=0$ \\
Boost & $D_{1} D_{2}^{2}-K\left(1-\frac{V_{\mathrm{f}}}{V_{\mathrm{g}}}\right) D_{2}+\frac{V_{\mathrm{f}}}{V_{\mathrm{g}}} \frac{R_{\mathrm{g}}+R_{\mathrm{L}}+R_{\mathrm{SW}}}{R} D_{1}-\frac{R_{\mathrm{SW}}}{R} D_{1} D_{2}-K D_{1}=0$ \\
Buck-Boost & $D_{1} D_{2}^{2}+\left(\frac{R_{\mathrm{L}}}{R} D_{1}-K \frac{V_{\mathrm{f}}}{V_{\mathrm{g}}}+\frac{V_{\mathrm{f}}}{V_{\mathrm{g}}} D_{1} \frac{R_{\mathrm{g}}+R_{\mathrm{L}}+R_{\mathrm{SW}}}{R}\right) D_{2}-K D_{1}=0$ \\
\hline
\end{tabular}

shown in table 4, where $K$ is termed as the conduction parameter, and is given by the following equation:

$$
K=\frac{2 \mathrm{~L}}{\mathrm{RT}_{\mathrm{S}}} .
$$

Similar equations for the other two converters are also shown in table 4 . These equations are used to calculate $D_{2}$, with knowledge of $D_{1}$. Under CCM, $D_{2}$ is calculated as $\left(1-D_{1}\right)$.

\subsection{Impact of non-idealities on diode duty ratio $\mathrm{D}_{2}$ and output voltage}

The variations of $D_{2}$ with duty cycle $D_{1}$ for the non-ideal buck, boost and buck-boost converters are plotted in figures 5(a), 5(b) and 5(c), respectively. The corresponding variations are also plotted, ignoring the non-idealities, on the same figures. It can be inferred from figure 5 that the change in $D_{2}$ on account of the non-idealities is not very significant, at least for the sets of parameters considered in this paper. Hence, the non-idealities could be ignored, and the simplified expressions as given in table 5 could be considered for the evaluation of $D_{2}$. Under CCM, $D_{2}$ is calculated as $\left(1-D_{1}\right)$.

However, the non-idealities have significant effect on the average output voltage as shown in table 6, which compares the ideal output voltage (ignoring the non-idealities) and the actual output voltages (considering the non-idealities) of the dc-dc converters at different operating conditions.

\subsection{Boundary condition between CCM and DCM}

At the boundary between the continuous and discontinuous condition modes of any converter, the duty ratios $D_{1}$ and $D_{2}$ are related as follows:

$$
D_{2}=\left(1-D_{1}\right) \text {. }
$$

This substitution can be made in the equations relating $D_{1}$ and $\mathrm{D}_{2}$ in table 4 , which considers the non-idealities. The value of $K$ at this boundary condition is termed as critical conduction parameter $K_{\text {cri }}$. The expressions for $K_{\text {cri }}$ for the three non-ideal converters are shown in table 7 . If the conduction parameter $K$, defined in (8), is greater than $K_{\text {cri }}$, then the operation is in CCM as indicated by (10); otherwise the operation is in DCM as indicated by (11).

$$
\begin{array}{ll}
K>K_{\text {cri }} & \text { for CCM } \\
K<K_{\text {cri }} \text { for DCM. }
\end{array}
$$




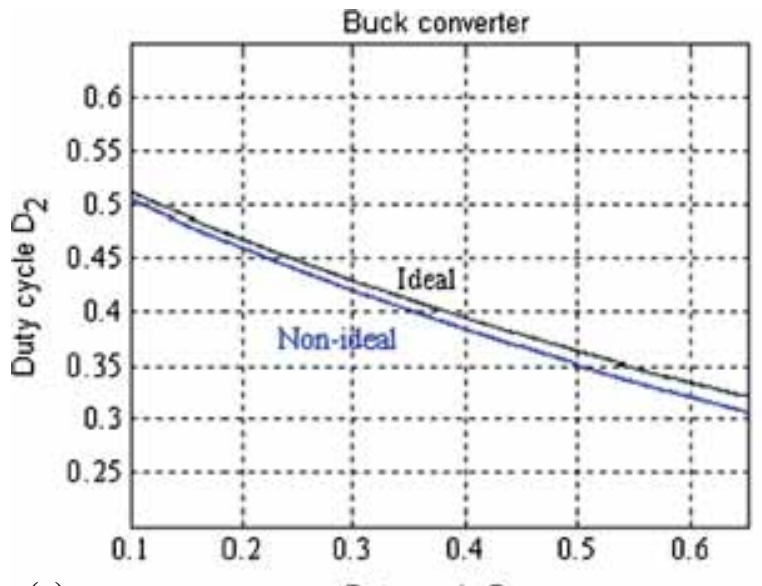

(a)

Duty cycle $D_{1}$

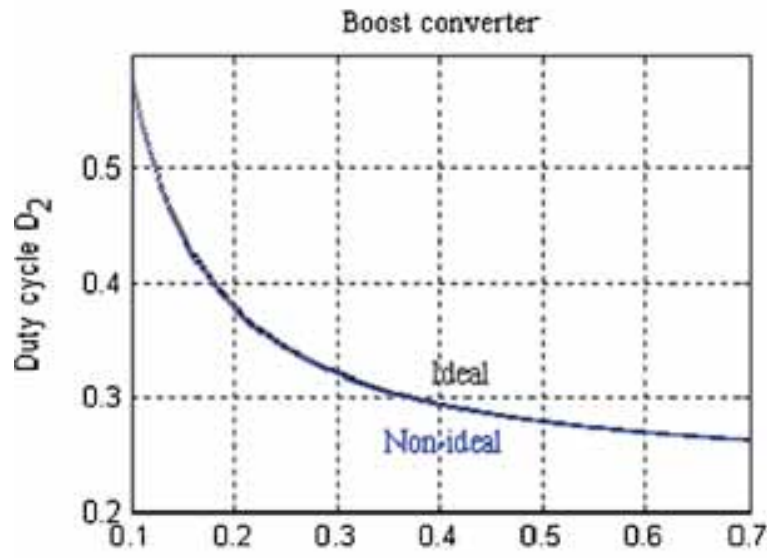

(b)

Duty cycle $D_{1}$

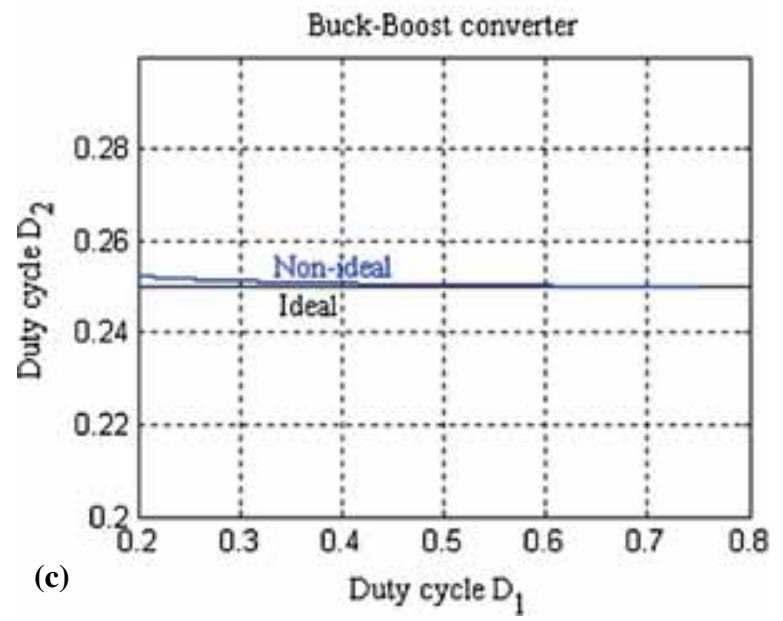

Figure 5. Variation of $D_{2}$ with $D_{1}$ for (a) buck (b) boost (c) buck-boost converter. 
Table 5. Calculation of duty cycle $D_{2}$ under DCM ignoring non-idealities.

\begin{tabular}{lc}
\hline Converter & $\frac{D_{2}}{\text { Buck }}$ \\
\hline Boost & $\frac{-D_{1}+\sqrt{D_{1}^{2}+4 K}}{2}$ \\
Buck-Boost & $\frac{K+\sqrt{K^{2}+4 D_{1}^{2} K}}{2 D_{1}}$ \\
\hline
\end{tabular}

Table 6. Comparison of ideal and non-ideal output voltage of dc-dc converters.

\begin{tabular}{lccccccc}
\hline $\begin{array}{l}\text { Converter } \\
\text { type }\end{array}$ & $\begin{array}{c}\text { Input } \\
\text { voltage } \\
V_{\mathrm{g}}\end{array}$ & $\begin{array}{c}\text { Duty } \\
\text { ratio } \\
D_{1}\end{array}$ & Mode & $\begin{array}{c}\text { Load } \\
\mathrm{R}(\Omega)\end{array}$ & $\begin{array}{c}\text { Switching } \\
\text { frequency } \\
f_{\mathrm{s}}(\mathrm{kHz})\end{array}$ & $\begin{array}{c}\text { Ideal output } \\
\text { voltage }\end{array}$ & $\begin{array}{c}\text { Non-ideal } \\
\text { output } \\
\text { voltage }\end{array}$ \\
\hline Buck & 40 & 0.5 & CCM & 200 & 20 & 20 & 19.4 \\
& 40 & 0.15 & DCM & 2,000 & 20 & 10.3 & 9.9 \\
Buck-Boost & 20 & 0.15 & DCM & 2,000 & 20 & 28 & 27.3 \\
& 20 & 0.5 & CCM & 200 & 20 & 20 & 17.83 \\
& 20 & 0.15 & DCM & 1,000 & 20 & 9.49 & 8.97 \\
\hline
\end{tabular}

Table 7. Value of $K_{\text {cri }}$ for various non-ideal dc-dc converters.

\begin{tabular}{lc}
\hline Type & \multicolumn{1}{c}{ Critical conduction parameter $K_{\text {cri }}$} \\
\hline Buck & $\frac{D_{1}^{2}\left(V_{\mathrm{g}}+V_{\mathrm{f}}-\frac{\left(R_{\mathrm{g}}+R_{\mathrm{SW}}\right)}{R} V_{\mathrm{f}}\right)-D_{1}\left(V_{\mathrm{g}}+\frac{R_{\mathrm{L}}}{R} V_{\mathrm{f}}+3 V_{\mathrm{f}}\right)+V_{\mathrm{f}}}{V_{\mathrm{f}}\left(1-D_{1}\right)-D_{1} V_{\mathrm{g}}}$ \\
Boost & $\frac{D_{1}^{3}+D_{1}^{2}\left(\frac{R_{\mathrm{SW}}}{R}-2\right)+D_{1}\left(1-\frac{R_{\mathrm{SW}}}{R}+\frac{V_{\mathrm{f}}}{V_{\mathrm{g}}}\left(\frac{R_{\mathrm{g}}+R_{\mathrm{L}}+R_{\mathrm{SW}}}{R}\right)\right)}{1-\frac{V_{\mathrm{f}}}{V_{\mathrm{g}}}\left(1-D_{1}\right)}$ \\
Buck-Boost & $\frac{D_{1}^{3}+D_{1}^{2}\left(-2-\frac{R_{\mathrm{L}}}{R}-\frac{V_{\mathrm{f}}}{V_{\mathrm{g}}} \frac{\left(R_{\mathrm{g}}+R_{\mathrm{L}}+R_{\mathrm{SW}}\right)}{R}\right)+D_{1}\left(1+\frac{R_{\mathrm{L}}}{R} \frac{V_{\mathrm{f}}}{V_{\mathrm{g}}} \frac{\left(R_{\mathrm{g}}+R_{\mathrm{L}}+R_{\mathrm{SW}}\right)}{R}\right)}{D_{1}+\frac{V_{\mathrm{f}}}{V_{\mathrm{g}}\left(1-D_{1}\right)}}$ \\
\hline
\end{tabular}

However, since $D_{2}$ is shown not to vary significantly due to the non-idealities, the simplified expressions for $D_{2}$ in table 5 can be used. Equating these expressions to $\left(1-D_{1}\right)$, much simplified expressions are obtained for $K_{\text {cri }}$ as shown in (12)-(14).

$$
\begin{gathered}
K_{\text {cri }}=1-D_{1} ; \quad \text { Buck } \\
K_{\text {cri }}=D_{1}\left(1-D_{1}\right)^{2} ; \text { Boost } \\
K_{\text {cri }}=\left(1-D_{1}\right)^{2} ; \text { Buck-Boost. }
\end{gathered}
$$


Table 8. Averaged value of $V_{\mathrm{p}}$ and $I_{\mathrm{D}}$ of the converters.

\begin{tabular}{lcc}
\hline Type of converter & Variable & Value \\
\hline Buck & $V_{\mathrm{p}}$ & $\left(V_{\mathrm{g}}-\frac{I_{\mathrm{L}}}{D_{1}+D_{2}}\left(R_{\mathrm{g}}+R_{\mathrm{SW}}\right)\right) D_{1}-\left(V_{\mathrm{f}}\right) D_{2}+V_{0}\left(1-D_{1}-D_{2}\right)$ \\
Boost & $V_{\mathrm{p}}$ & $\frac{I_{\mathrm{L}}}{D_{1}+D_{2}} R_{\mathrm{SW}} D_{1}+\left\{\left(V_{0}+V_{\mathrm{f}}\right) D_{2}\right\}+V_{\mathrm{g}}\left(1-D_{1}-D_{2}\right)$ \\
& $I_{\mathrm{D}}$ & $I_{\mathrm{L}} \frac{D_{2}}{D_{1}+D_{2}}$ \\
Buck-Boost & $V_{\mathrm{p}}$ & $\left(V_{\mathrm{g}}-\left(R_{\mathrm{g}}+R_{\mathrm{SW}}\right) \frac{I_{\mathrm{L}}}{D_{1}+D_{2}}\right) D_{1}+\left(-V_{0}-V_{\mathrm{f}}\right) D_{2}$ \\
& $I_{\mathrm{D}}$ & $I_{\mathrm{L}} \frac{D_{2}}{D_{1}+D_{2}}$ \\
\hline
\end{tabular}

\subsection{Dynamic average modeling}

The dynamic average modeling of the converters is represented by the block diagram in figure $3 \mathrm{~b}$. The average pole voltage $V_{\mathrm{p}}$ is determined using the input voltage $V_{\mathrm{g}}$, duty cycle $D_{1}$ and diode duty cycle $D_{2}$ as indicated in the figure. Table 8 shows the expressions for $V_{\mathrm{P}}$ used in the average models of the three converters. The average pole voltage $V_{\mathrm{p}}$ is used to evaluate the average inductor current $I_{\mathrm{L}}$ as mentioned earlier. The relation between the average inductor current $I_{\mathrm{L}}$ and the average diode current $I_{\mathrm{D}}$ is also shown for the boost and buck-boost converters in the same table. The average diode current is used to determine the average capacitor voltage and average output voltage as shown in figure 3(b).

\section{Harmonic model}

The value of peak to peak ripple in various currents and voltages of the converter is given by the harmonic model. The ripple in inductor current $\left(\Delta I_{\mathrm{L}}\right)$, capacitor voltage $\left(\Delta V_{\mathrm{C}}\right)$ and output voltage $\left(\Delta V_{0}\right)$ are provided by the harmonic model, using the results from the average model of the converter, as shown in figure $3 \mathrm{c}$. The harmonic model of various converters is discussed in the following sections.

\subsection{Harmonic model of buck converter}

In buck converter, shown in figure $1(\mathrm{a})$, the average inductor current $\left(I_{\mathrm{L}}\right)$ is equal to the load current $\left(I_{0}\right)$. The ripple in inductor current $\left(\Delta I_{\mathrm{L}}\right)$ passes through the capacitor $\left(\Delta I_{\mathrm{c}}\right)$ i.e. $\Delta I_{\mathrm{C}}=$ $\Delta I_{\mathrm{L}}$. Under CCM, the inductor current $i_{\mathrm{L}}$ is continuous and is plotted in figure 6(a). The ripple component of $i_{\mathrm{L}}$ (i.e. $i_{\mathrm{L}}-i_{0}$ ) flows through the capacitor, as shown in figure 6(b). The integral of capacitor current, divided by the capacitance $\mathrm{C}$, gives the value of capacitor ripple voltage $\left(\Delta V_{\mathrm{C}}\right)$ (figure 6(c)). The drop across the series resistance $\left(R_{\mathrm{c}}\right)$ of the capacitor has the same shape as that of capacitor current. The sum of drop across $R_{\mathrm{c}}$ and the voltage ripple across $\mathrm{C}$ gives the value of output voltage ripple $\left(\Delta V_{\mathrm{o}}\right)$, as shown in figure $6(\mathrm{~d})$.

Under DCM, the inductor current is zero during certain interval in the switching cycle, as shown in figure 7(a). The capacitor current under DCM operation is shown in figure 7(b). The capacitor ripple voltage and output voltage ripple are plotted in figure 7(c) and 7(d) respectively.

The value of inductor ripple current is calculated from the voltage across the inductor during $\mathrm{ON}$ or OFF period of the switch. The value of $\Delta I_{\mathrm{L}}$ under CCM/DCM operation of buck converter 

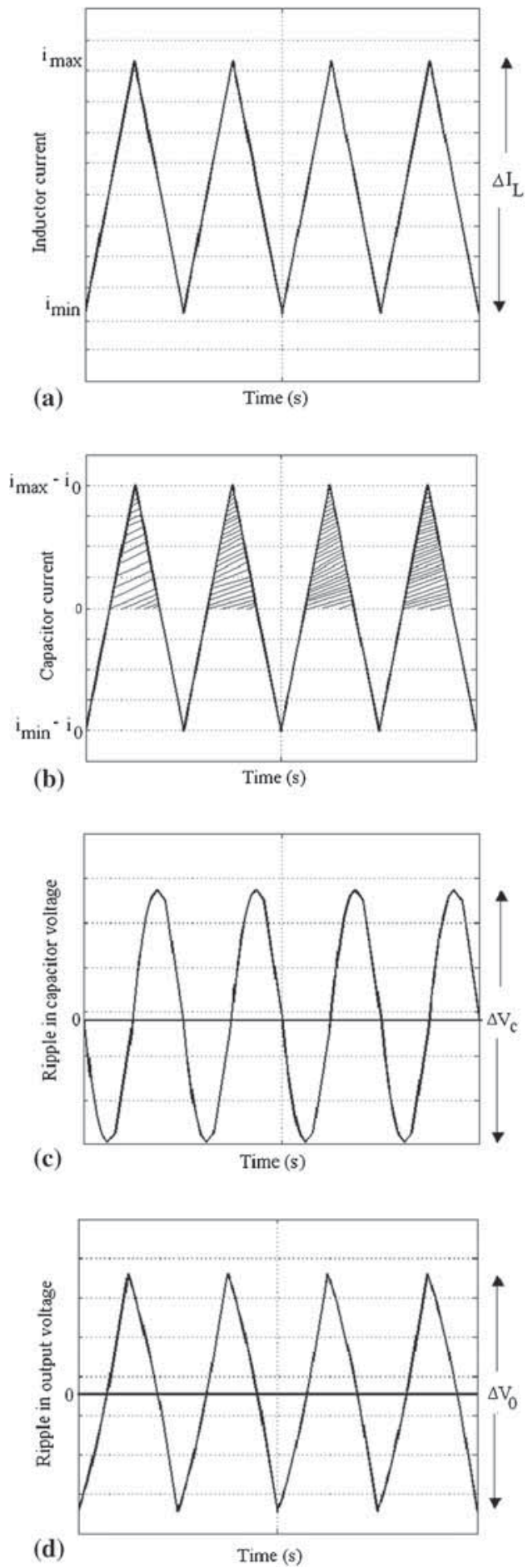

Figure 6. Buck converter under CCM (a) inductor current (b) capacitor current (c) capacitor voltage (d) output voltage. 

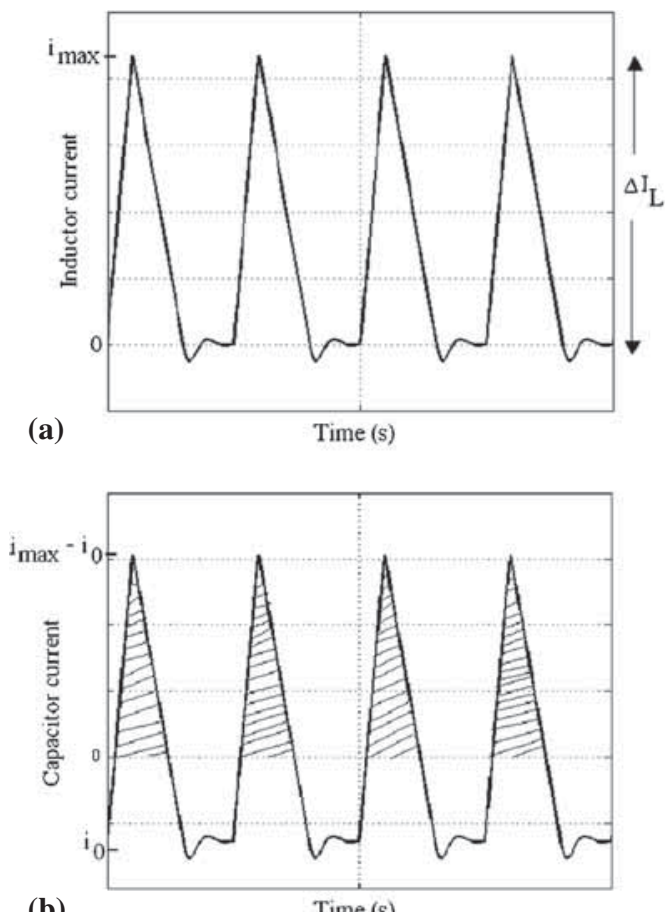

(b)

Time (s)
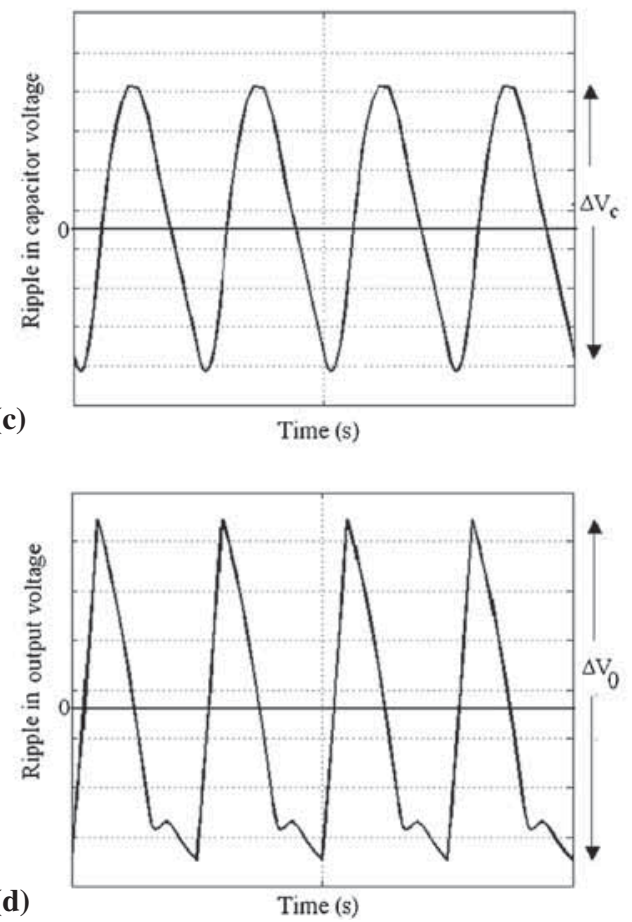

Figure 7. Buck converter under DCM (a) inductor current (b) capacitor current (c) ripple in capacitor voltage (d) ripple in output voltage. 
Table 9. Output of harmonic model of buck converter.

\begin{tabular}{lcc}
\hline \multirow{2}{*}{ Variable } & \multicolumn{2}{c}{ Operation mode } \\
\cline { 2 - 3 }$\Delta I_{\mathrm{L}}$ & $\frac{\left(I_{\mathrm{L}} R_{\mathrm{L}}+V_{\mathrm{O}}+V_{\mathrm{f}}\right) *\left(1-D_{1}\right) T_{\mathrm{S}}}{L}$ & $\frac{\left(I_{\mathrm{L}} R_{\mathrm{L}}+V_{\mathrm{O}}+V_{\mathrm{f}}\right) * D_{2} T_{\mathrm{S}}}{L}$ \\
\cline { 2 - 3 }$\Delta V_{\mathrm{C}}$ & $\frac{\Delta I_{\mathrm{L}} T_{\mathrm{S}}}{8 \mathrm{C}}$ & $\frac{\left(D_{1}+D_{2}\right) T_{\mathrm{S}}\left(\Delta I_{\mathrm{L}}-I_{\mathrm{o}}\right)^{2}}{2 C \Delta I_{\mathrm{L}}}$ \\
\hline
\end{tabular}

Table 10. Output of harmonic model of Boost and Buck-Boost converters.

\begin{tabular}{lcc}
\hline Variable & \multicolumn{2}{c}{ Operation mode } \\
\cline { 2 - 3 }$\Delta I_{\mathrm{L}}$ & $\frac{\left(V_{\mathrm{g}}-I_{\mathrm{L}}\left(R_{\mathrm{g}}+R_{\mathrm{SW}}+R_{\mathrm{L}}\right)\right) D_{1} T_{\mathrm{S}}}{L}$ & DCM \\
$\Delta V_{\mathrm{C}}\left(I_{\mathrm{o}}<I_{\min }\right)$ & $\frac{V_{0} D_{1} T_{\mathrm{S}}}{R C}$ & $\frac{\left(V_{\mathrm{g}}-I_{\mathrm{L}}\left(R_{\mathrm{g}}+R_{\mathrm{Sw}}+R_{\mathrm{L}}\right)\right) D_{1} T_{\mathrm{S}}}{L}$ \\
$\Delta V_{\mathrm{C}}\left(I_{\mathrm{O}}>I_{\min }\right)$ & $\frac{\left(I_{\max }-I_{\mathrm{O}}\right)^{2}\left(1-D_{1}\right) T_{\mathrm{S}}}{2\left(\Delta I_{\mathrm{L}}\right) C}$ & $\frac{D_{2} T_{\mathrm{S}}\left(I_{\max }-I_{\mathrm{o}}\right)^{2}}{\left.2 C I_{\mathrm{o}}\right)^{2}}$ \\
\hline
\end{tabular}

is given in table 9. The value of capacitor ripple voltage is calculated from $\Delta I_{\mathrm{L}}$ and is tabulated in table 9 . The value of output ripple voltage is given by

$$
\Delta V_{\mathrm{o}}^{2}=\Delta V_{c}^{2}+\left(\Delta I_{C} R_{c}\right)^{2} .
$$

Depending on the relative magnitude of $\Delta I_{\mathrm{c}}$ or $\Delta V_{\mathrm{C}}$, the output ripple voltage $\Delta V_{\mathrm{o}}$ is approximated as

$$
\Delta V_{\mathrm{o}}=\Delta V_{c} ; \text { or } \Delta V_{\mathrm{o}}=\Delta I_{C} R_{c} .
$$

\subsection{Harmonic model of boost converter}

In an ideal boost converter, the voltage across the inductor is $V_{\mathrm{g}}$ or $\left(V_{\mathrm{g}}-V_{\mathrm{o}}\right)$ or zero; depending on the conduction of switch and diode. In a non-ideal boost converter, the voltage across the inductor reduces from its ideal value by the drop in resistive non-idealities. During ON period of the switch (i.e. $D_{1} T_{\mathrm{S}}$ ), the drop is calculated using the average value of inductor current, obtained from the average model of boost converter. The value of ripple in inductor current is given by the expression, tabulated in table 10.

When the switch is OFF i.e. during $\left(1-D_{1}\right) T_{\mathrm{s}}$ or $D_{2} T_{\mathrm{s}}$, the inductor current flows through the diode. The average diode current is equal to the load current $\left(I_{0}\right)$. The ripple in diode current flows through the capacitor.

Under CCM, the minimal value of inductor current is indicated as $i_{\min }$, as shown in figure 8(a). When the load current $i_{0}$ is less than $i_{\text {min }}$, the capacitor ripple current is plotted in figure 8(b). From the capacitor ripple current, the ripple in capacitor voltage $\left(\Delta V_{\mathrm{C}}\right)$ is determined as shown in figure $8(\mathrm{c})$. The output voltage ripple is given by the sum of resistive drop across $R_{\mathrm{c}}$ and $\Delta V_{\mathrm{C}}$, as plotted in figure $8(\mathrm{~d})$.

Under CCM, when the load current $i_{\mathrm{O}}$ is higher than the minimal value of inductor current $i_{\min }$, the shape of ripple current through the capacitor varies, as shown in figure $9(\mathrm{~b})$. The capacitor 

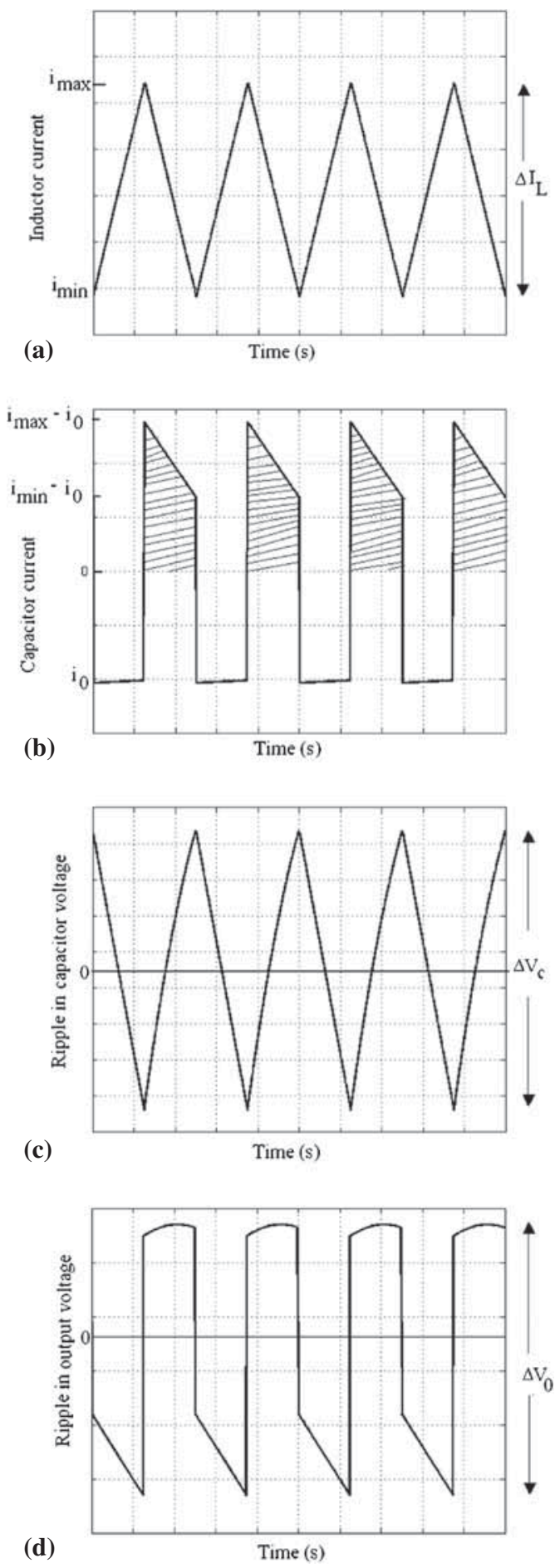

Figure 8. Boost converter under CCM when $i_{0}<i_{\min }$ (a) inductor current (b) capacitor current (c) ripple in capacitor voltage $(\mathbf{d})$ ripple in output voltage. 
(a)
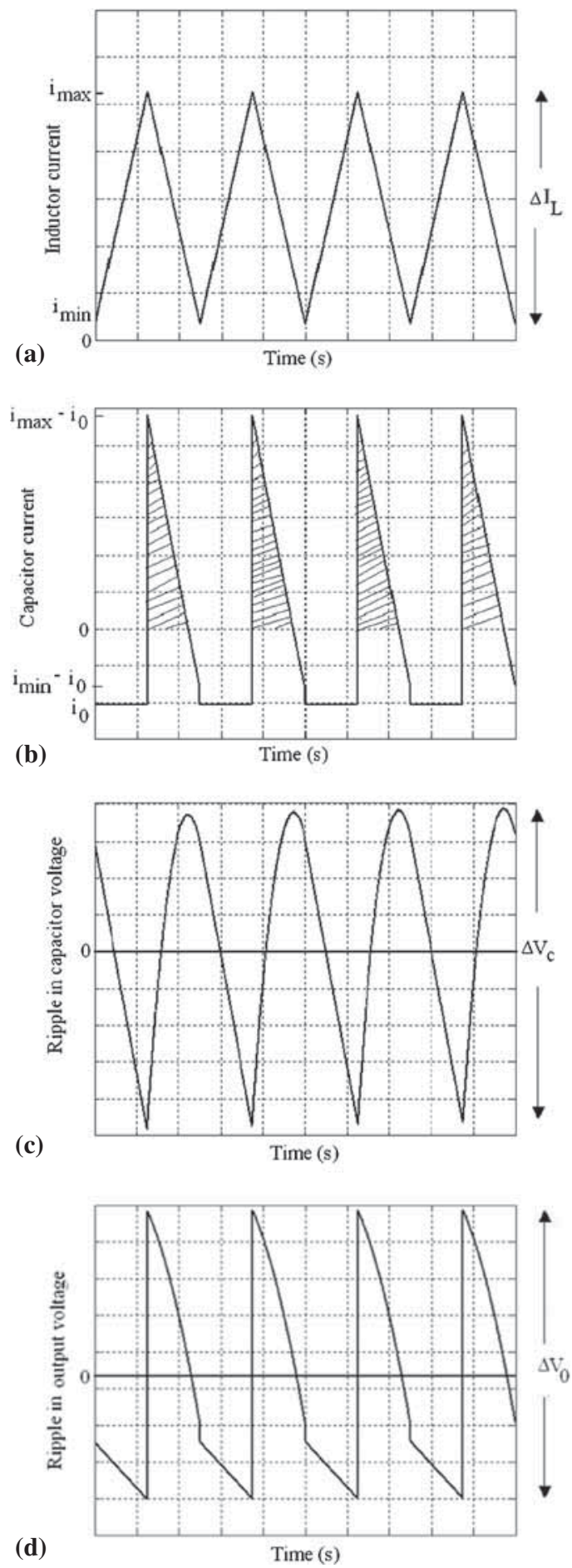

Figure 9. Boost converter under CCM when $i_{0}>i_{\min }$ (a) inductor current (b) capacitor current (c) ripple in capacitor voltage $(\mathbf{d})$ ripple in output voltage. 
ripple voltage and output ripple voltage under this mode of operation is shown in figure 9(c) and 9(d) respectively. Under DCM, the minimal value of inductor current is zero. The capacitor current has the same shape, similar to that shown in figure 9(b).
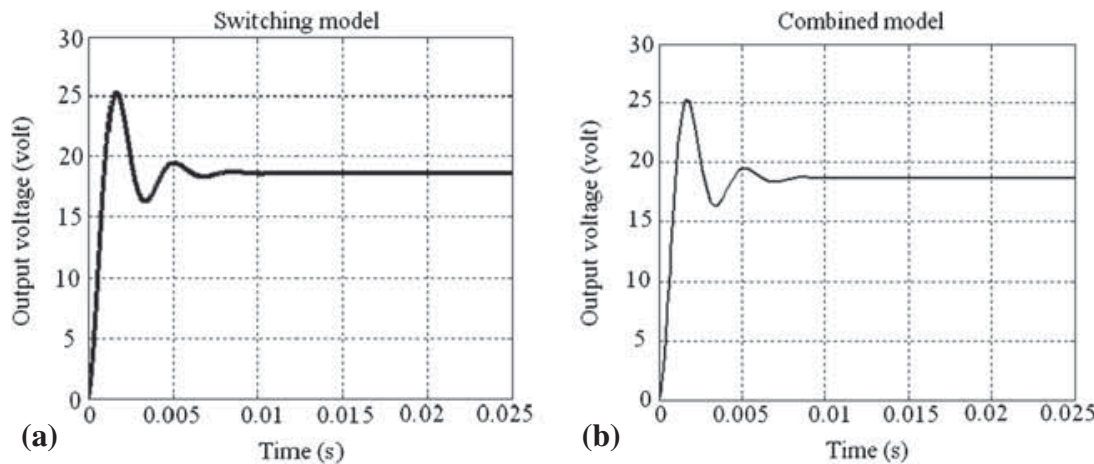

Figure 10. Output voltage of buck converter: $D_{1}=0.53, R=100 \Omega, V_{\mathrm{g}}=40 \mathrm{~V}$ (a) switching model (b) combined model.
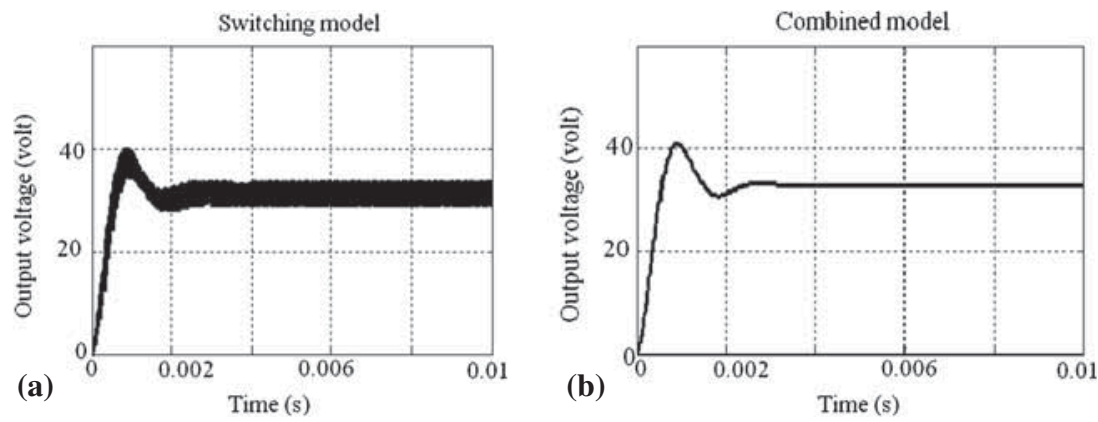

Figure 11. Output voltage of boost converter: $D_{1}=0.48, R=50 \Omega, V_{\mathrm{g}}=20 \mathrm{~V}$ (a) switching model (b) combined model.
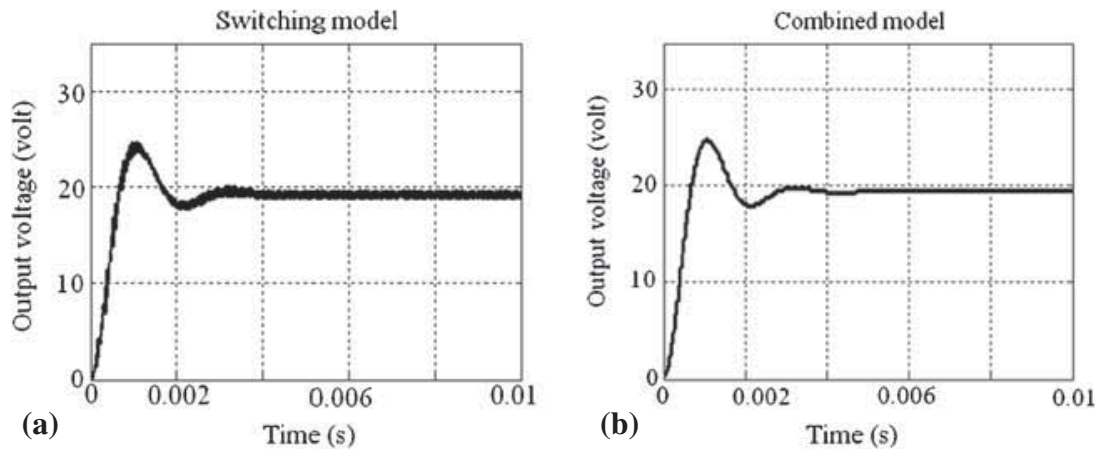

Figure 12. Output voltage of Buck-Boost converter: $D_{1}=0.54, R=100 \Omega, V_{\mathrm{g}}=20 \mathrm{~V}$ (a) switching model (b) combined model. 

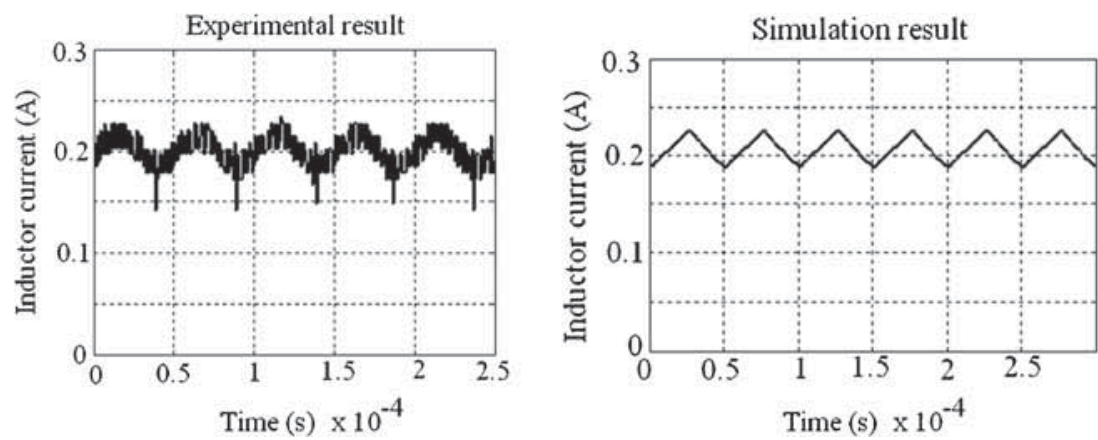

Figure 13. Inductor current of buck converter under CCM: $D_{1}=0.53, R=100 \Omega, V_{\mathrm{g}}=40 \mathrm{~V}, f_{\mathrm{s}}=$ $20 \mathrm{kHz}$.
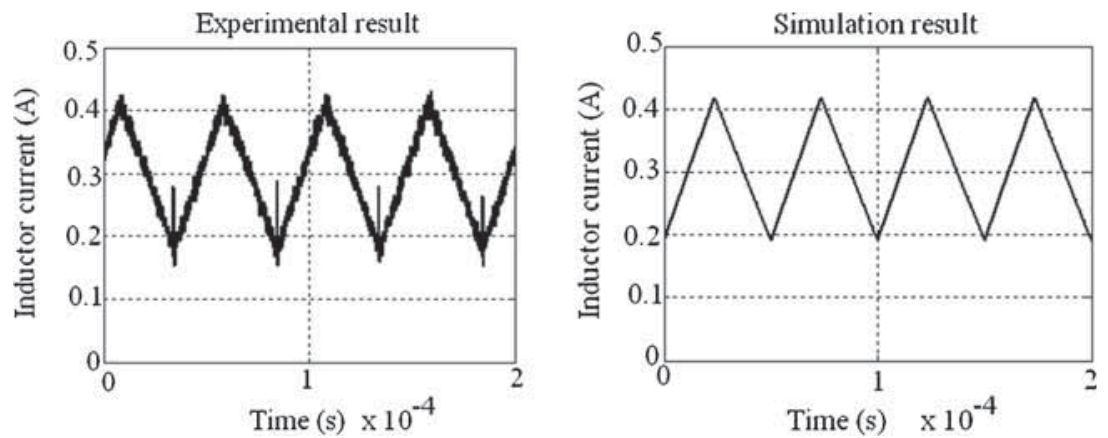

Figure 14. Inductor current of boost converter under CCM: $D_{1}=0.48, R=222 \Omega, V_{\mathrm{g}}=20 \mathrm{~V}, f_{\mathrm{s}}=$ $20 \mathrm{kHz}$.
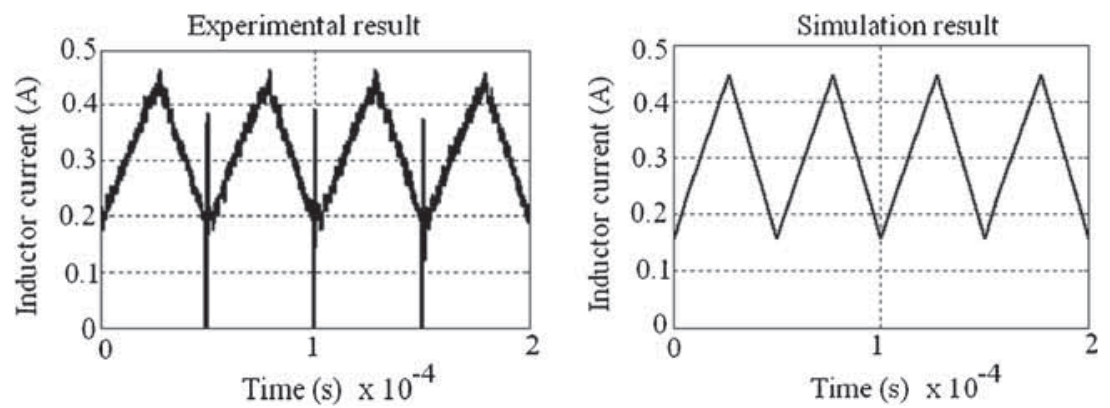

Figure 15. Inductor current of buck-boost converter under CCM: $D_{1}=0.54, R=222 \Omega, V_{\mathrm{g}}=20 \mathrm{~V}$, $f_{\mathrm{s}}=20 \mathrm{kHz}$.

The ripple in capacitor voltage $\left(\Delta V_{\mathrm{c}}\right)$ is calculated as the time integral of positive value of capacitor current, as shown by dashed lines in figures $8-9$. The value of $\Delta V_{\mathrm{c}}$ under various operation modes of the boost converter is tabulated in table 10. The ripple in output voltage is determined using (15) and (16). 

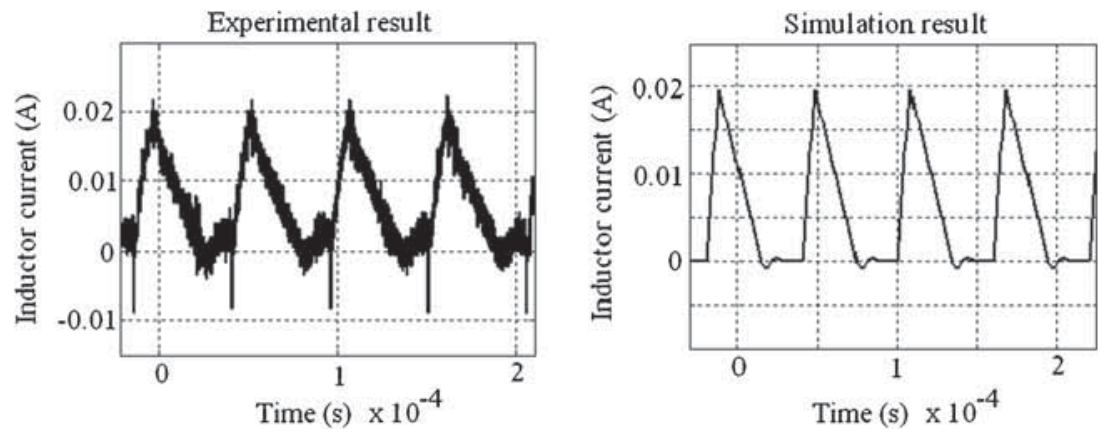

Figure 16. Inductor current of buck converter under DCM: $D_{1}=0.12, R=1,600 \Omega, V_{\mathrm{g}}=40 \mathrm{~V}$, $f_{\mathrm{s}}=16.8 \mathrm{kHz}$.
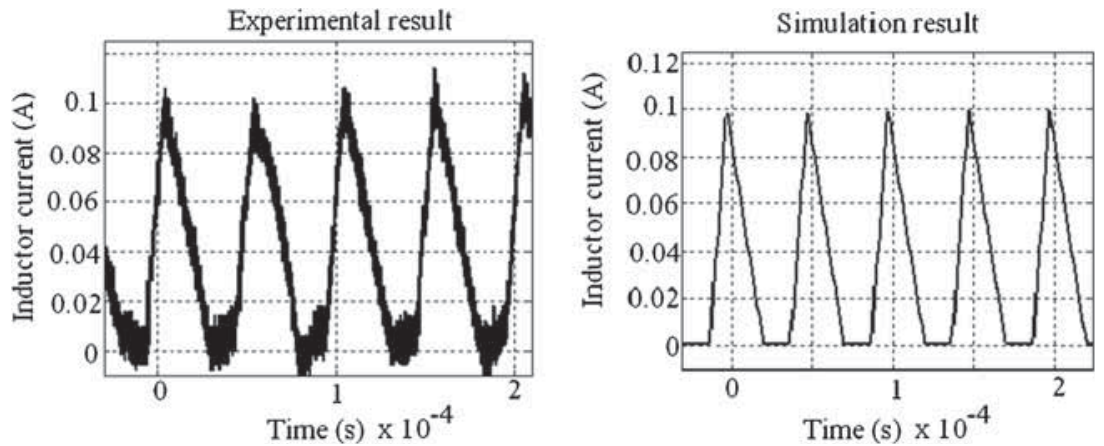

Figure 17. Inductor current of boost converter under DCM: $D_{1}=0.48, R=1,600 \Omega, V_{\mathrm{g}}=20 \mathrm{~V}$, $f_{\mathrm{s}}=20 \mathrm{kHz}$.
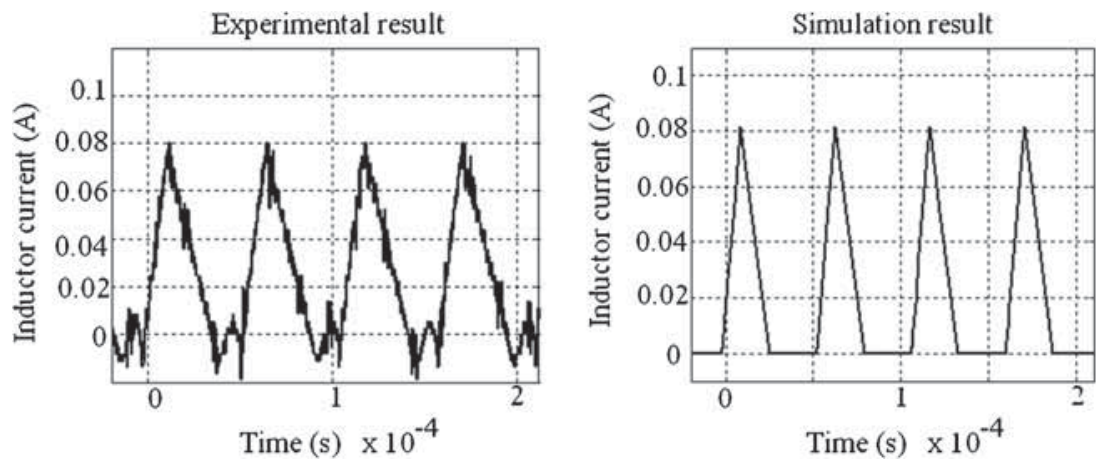

Figure 18. Inductor current of buck-boost converter under DCM: $D_{1}=0.12, \mathrm{R}=980 \Omega, V_{\mathrm{g}}=20 \mathrm{~V}$, $f_{\mathrm{s}}=18.5 \mathrm{kHz}$.

\subsection{Harmonic model of buck-boost converter}

In a buck-boost converter, the inductor current flows through the diode during off-time of active switch. The average diode current flows through the load. The ripple in diode current flows 

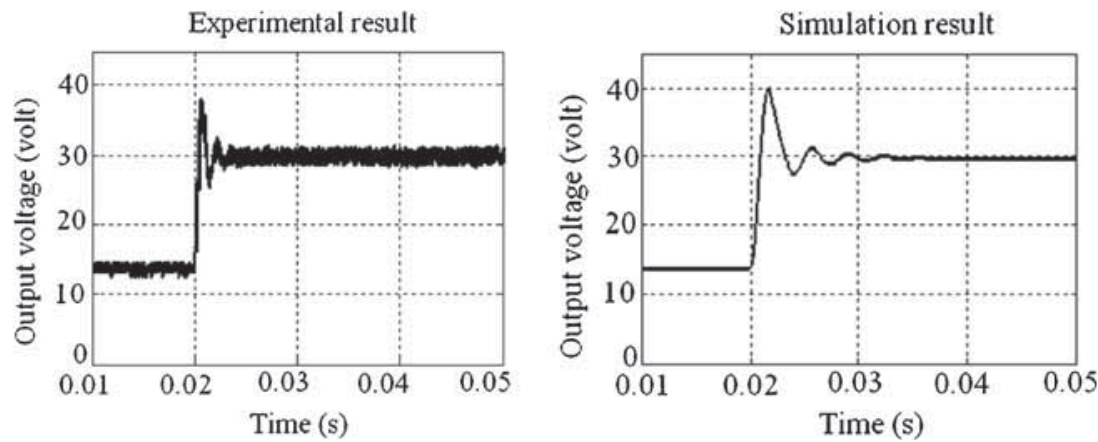

Figure 19. Output voltage transient for buck converter under: $D_{1}=0.36$ to $0.56, R=100 \Omega, V_{\mathrm{g}}=40 \mathrm{~V}$, $f_{\mathrm{s}}=20 \mathrm{kHz}$.
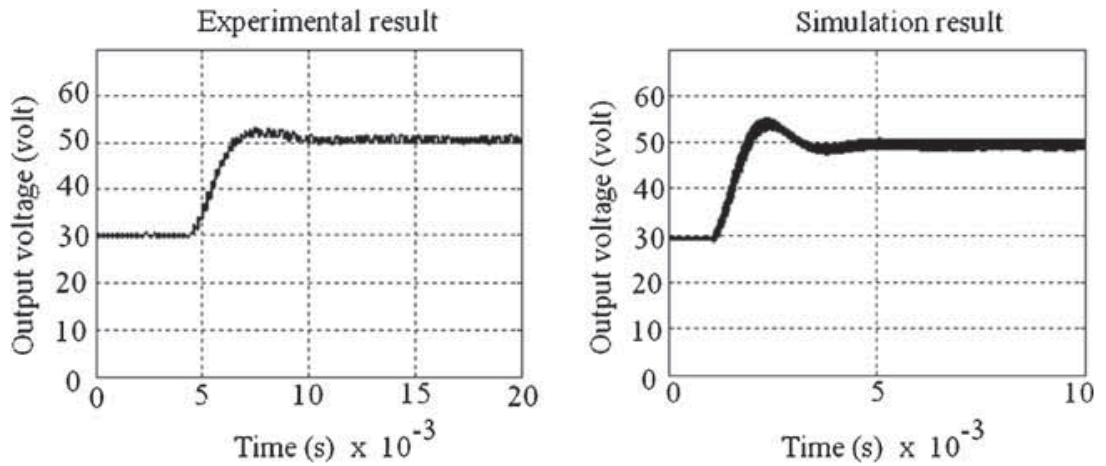

Figure 20. Output voltage of boost converter: $D_{1}=0.36$ to $0.64, R=222 \Omega, V_{\mathrm{g}}=20 \mathrm{~V}, f_{\mathrm{s}}=20 \mathrm{kHz}$.
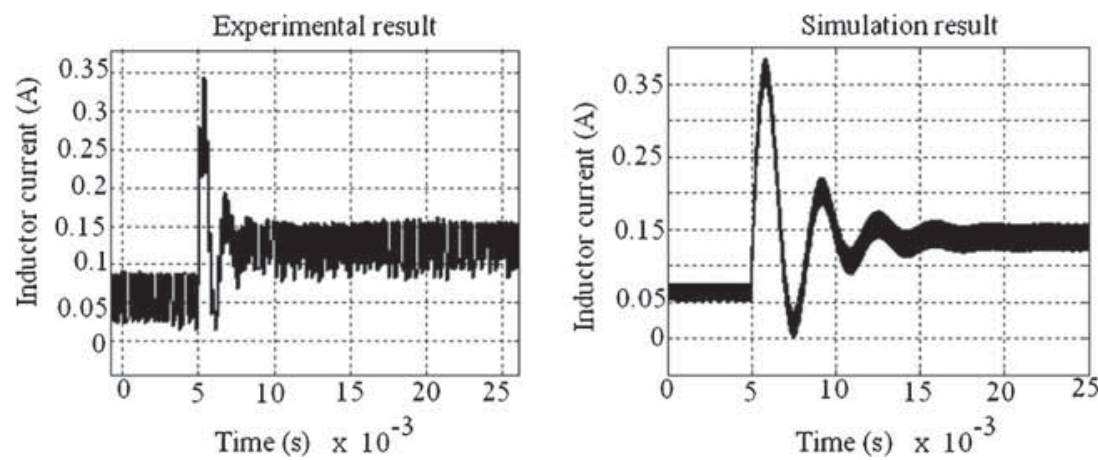

Figure 21. Inductor current in a buck converter for a step change in $D_{1}$ from 0.36 to $0.56, R=100 \Omega$, $V_{\mathrm{g}}=40 \mathrm{~V}, f_{\mathrm{s}}=20 \mathrm{kHz}$.

through the capacitor. From the perspective of ripple current and voltage, the structure is much similar to that of boost converter. The value of $\Delta I_{\mathrm{L}}$ and $\Delta V_{\mathrm{c}}$ under various modes of operation of buck-boost converter is tabulated in table 10 . 

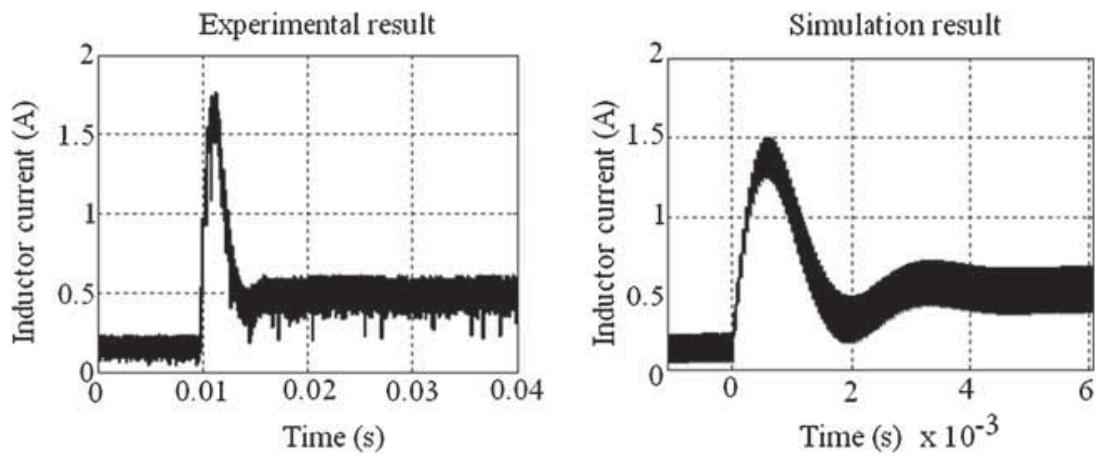

Figure 22. Inductor current in a boost converter for a step change in $D_{1}$ from 0.36 to $0.64, R=222 \Omega$, $V_{\mathrm{g}}=20 \mathrm{~V}, f_{\mathrm{s}}=20 \mathrm{kHz}$.

Table 11. Comparison of simulation and experimental results from buck converter: $V_{\mathrm{g}}=40 \mathrm{~V}$.

\begin{tabular}{llllccc}
\hline Parameter & Mode & $D_{1}$ & $R(\Omega)$ & Experimental result & Combined model & Switching model \\
\hline Output & CCM & 0.5 & 100 & 20.01 & 20.35 & 20.35 \\
voltage $\left(V_{\mathrm{o}}\right)$ & DCM & 0.2 & 1,170 & 27.4 & 27.67 & 27.625 \\
Inductor & CCM & 0.5 & 100 & 0.2 & 0.203 & 0.203 \\
current $\left(I_{\mathrm{L}}\right)$ & DCM & 0.2 & 1,170 & 0.038 & 0.04857 & 0.036 \\
Inductor ripple & CCM & 0.5 & 100 & 0.04 & 0.04 & 0.04 \\
current $\left(\Delta I_{\mathrm{L}}\right)$ & DCM & 0.2 & 1,170 & 0.105 & 0.106 & 0.102 \\
Output ripple & CCM & 0.5 & 100 & 0.06 & 0.0578 & 0.058 \\
voltage $\left(\Delta V_{\mathrm{o}}\right)$ & DCM & 0.2 & 1,170 & 0.58 & 0.3585 & 0.3 \\
\hline
\end{tabular}

Table 12. Comparison of simulation and experimental results from boost converter: $\mathrm{V}_{\mathrm{g}}=20 \mathrm{~V}$.

\begin{tabular}{llllccc}
\hline Parameter & Mode & $D_{1}$ & $R(\Omega)$ & Experimental result & Combined model & Switching model \\
\hline Output & CCM & 0.48 & 222 & 35.62 & 36.43 & $36 \mathrm{~V}$ \\
voltage $\left(V_{\mathrm{o}}\right)$ & DCM & 0.2 & 1,170 & 27.4 & 27.67 & 27.625 \\
Inductor & CCM & 0.48 & 222 & 0.3 & 0.3125 & 0.315 \\
current $\left(I_{\mathrm{L}}\right)$ & DCM & 0.2 & 1,170 & 0.038 & 0.04857 & 0.036 \\
Inductor ripple & CCM & 0.48 & 222 & 0.25 & 0.2322 & 0.235 \\
current $\left(\Delta I_{\mathrm{L}}\right)$ & DCM & 0.2 & 1,170 & 0.105 & 0.106 & 0.102 \\
Output ripple & CCM & 0.48 & 222 & 1.2 & 1.52 & 1.2 \\
voltage $\left(\Delta V_{\mathrm{o}}\right)$ & DCM & 0.2 & 1,170 & 0.58 & 0.3585 & 0.3 \\
\hline
\end{tabular}

Table 13. Comparison of simulation and experimental results from buck-boost converter: $\mathrm{V}_{\mathrm{g}}=20 \mathrm{~V}$.

\begin{tabular}{llccccc}
\hline Parameter & Mode & $D_{1}$ & $R(\Omega)$ & Experimental result & Combined model & Switching model \\
\hline Output & CCM & 0.55 & 222 & 21.43 & 21.9 & 21.9 \\
voltage $\left(V_{\mathrm{o}}\right)$ & DCM & 0.13 & 980 & 7.2 & 7.22 & 7.55 \\
Inductor & CCM & 0.55 & 222 & 0.246 & 0.22 & 0.22 \\
current $\left(I_{\mathrm{L}}\right)$ & DCM & 0.13 & 980 & 0.1 & 0.0103 & 0.0105 \\
Inductor ripple & CCM & 0.55 & 222 & 0.21 & 0.21 & 0.21 \\
current $\left(\Delta I_{\mathrm{L}}\right)$ & DCM & 0.13 & 980 & 0.66 & 0.052 & 0.052 \\
Output ripple & CCM & 0.55 & 222 & 0.8 & 0.47 & 0.4 \\
voltage $\left(\Delta V_{\mathrm{o}}\right)$ & DCM & 0.13 & 980 & 0.7 & 0.0542 & 0.4 \\
\hline
\end{tabular}


Table 14. Comparison of computational time under steady-state condition of converters.

\begin{tabular}{lcclcccc}
\hline Type & Mode & $D_{1}$ & $\begin{array}{l}R \\
(\Omega)\end{array}$ & $\begin{array}{c}\text { Duration } \\
(\mathrm{s})\end{array}$ & $\begin{array}{c}\text { Switching } \\
\text { model }(\mathrm{s})\end{array}$ & $\begin{array}{c}\text { Average } \\
\text { model }(\mathrm{s})\end{array}$ & $\begin{array}{c}\text { Combined } \\
\text { model (s) }\end{array}$ \\
\hline Buck & CCM & 0.8 & 100 & 0.2 & 11.53 & 0.505 & 0.817 \\
& DCM & 0.2 & 1,610 & 0.5 & 29.34 & 1.479 & 1.806 \\
Boost & CCM & 0.4 & 222 & 0.2 & 9.1 & 0.479 & 0.665 \\
\multirow{3}{*}{ Buck-Boost } & DCM & 0.2 & 1,600 & 0.5 & 23.84 & 1.291 & 1.321 \\
& CCM & 0.54 & 222 & 0.2 & 14.47 & 0.528 & 0.552 \\
& DCM & 0.2 & 1,500 & 0.5 & 39.87 & 1.344 & 1.688 \\
\hline
\end{tabular}

Table 15. Comparison of computation time among switching, average and combined models under transient conditions for buck converter.

\begin{tabular}{|c|c|c|c|c|}
\hline Transition & Mode & $\begin{array}{l}\text { Switching } \\
\text { model (s) }\end{array}$ & $\begin{array}{l}\text { Average } \\
\text { model (s) }\end{array}$ & $\begin{array}{l}\text { Combined } \\
\text { model (s) }\end{array}$ \\
\hline $\begin{array}{l}\text { Step change in } D_{1} \text { from } \\
0.4 \text { to } 0.8 ; V_{\mathrm{g}}=40 \mathrm{~V}, R=222 \Omega\end{array}$ & $\mathrm{CCM}$ & 1.262 & 0.1062 & 0.1095 \\
\hline $\begin{array}{l}\text { Step change in } D_{1} \text { from } 0.6 \text { to } \\
0.2 ; V_{\mathrm{g}}=40 \mathrm{~V}, R=222 \Omega\end{array}$ & $\mathrm{CCM}$ & 1.305 & 0.0492 & 0.084 \\
\hline $\begin{array}{l}\text { Step change in } D_{1} \text { from } 0.2 \text { to } \\
0.4 ; V_{\mathrm{g}}=40 \mathrm{~V}, R=2,500 \Omega\end{array}$ & DCM & 5.641 & 0.1664 & 0.276 \\
\hline $\begin{array}{l}\text { Step change in } D_{1} \text { from } 0.5 \text { to } \\
0.25 ; V_{\mathrm{g}}=40 \mathrm{~V}, R=2,500 \Omega\end{array}$ & DCM & 4.437 & 0.1293 & 0.2279 \\
\hline $\begin{array}{l}\text { Step change in } R \text { from } 750 \Omega \text { to } \\
150 \Omega ; V_{\mathrm{g}}=40 \mathrm{~V} ; D_{1}=0.8\end{array}$ & $\mathrm{CCM}$ & 4.0511 & 0.1291 & 0.1398 \\
\hline $\begin{array}{r}\text { Step change in } R \text { from } 200 \Omega \text { to } \\
1,000 \Omega ; V_{\mathrm{g}}=40 \mathrm{~V}, D_{1}=0.8\end{array}$ & CCM & 6.4978 & 0.0458 & 0.09701 \\
\hline $\begin{array}{l}\text { Step change in } R \text { from } 2,250 \Omega \text { to } \\
1,750 \Omega ; V_{\mathrm{g}}=40 \mathrm{~V}, D_{1}=0.2\end{array}$ & DCM & 3.582 & 0.052 & 0.1121 \\
\hline $\begin{array}{l}\text { Step change in } R \text { from } 1,750 \Omega \text { to } \\
2,250 \Omega ; V_{\mathrm{g}}=40 \mathrm{~V}, D_{1}=0.2\end{array}$ & DCM & 3.583 & 0.0512 & 0.112 \\
\hline $\begin{array}{l}\text { Step change in } R \text { from } 150 \Omega \text { to } \\
1,750 \Omega ; V_{\mathrm{g}}=40 \mathrm{~V}, D_{1}=0.2\end{array}$ & $\begin{array}{l}\text { CCM to } \\
\text { DCM }\end{array}$ & 4.573 & 0.1403 & 0.184 \\
\hline $\begin{array}{l}\text { Step change in } R \text { from } 2,500 \Omega \text { to } \\
250 \Omega ; V_{\mathrm{g}}=40 \mathrm{~V}, D_{1}=0.4\end{array}$ & $\begin{array}{l}\text { DCM to } \\
\text { CCM }\end{array}$ & 2.237 & 1.1312 & 0.1392 \\
\hline $\begin{array}{c}\text { Step change in } V_{\mathrm{g}} \text { from } 35 \mathrm{~V} \text { to } \\
45 \mathrm{~V} ; D_{1}=0.65, R=100 \Omega\end{array}$ & $\mathrm{CCM}$ & 1.511 & 0.0516 & 0.0794 \\
\hline $\begin{array}{l}\text { Step change in } V_{\mathrm{g}} \text { from } 45 \mathrm{~V} \text { to } \\
35 \mathrm{~V} ; D_{1}=0.65, R=500 \Omega\end{array}$ & $\mathrm{CCM}$ & 2.2602 & 0.0847 & 0.0892 \\
\hline $\begin{array}{l}\text { Step change in } V_{\mathrm{g}} \text { from } 45 \mathrm{~V} \text { to } \\
35 \mathrm{~V} ; D_{1}=0.2, R=1,600 \Omega\end{array}$ & DCM & 6.769 & 0.1185 & 0.1461 \\
\hline $\begin{array}{l}\text { Step change in } V_{\mathrm{g}} \text { from } 35 \mathrm{~V} \text { to } \\
45 \mathrm{~V} ; D_{1}=0.2, R=2,500 \Omega\end{array}$ & DCM & 11.0474 & 0.1318 & 0.3401 \\
\hline
\end{tabular}

\section{Validation of simulation models}

The harmonic and average models are combined together and referred as "combined model" in this paper for further discussion. This section discusses the comparison of combined 
Table 16. Comparison of computation time among switching, average and combined models under transient conditions for boost converter.

\begin{tabular}{|c|c|c|c|c|}
\hline Transition & Mode & $\begin{array}{l}\text { Switching } \\
\text { model (s) }\end{array}$ & $\begin{array}{l}\text { Average } \\
\text { model (s) }\end{array}$ & $\begin{array}{l}\text { Combined } \\
\text { model (s) }\end{array}$ \\
\hline $\begin{array}{l}\text { Step change in } D_{1} \text { from } 0.3 \text { to } \\
0.5 ; V_{\mathrm{g}}=21.4 \mathrm{~V}, R=105 \Omega\end{array}$ & $\mathrm{CCM}$ & 4.537 & 0.0707 & 0.177 \\
\hline $\begin{array}{l}\text { Step change in } D_{1} \text { from } 0.7 \text { to } \\
0.2 ; V_{\mathrm{g}}=21.4 \mathrm{~V}, R=105 \Omega\end{array}$ & $\mathrm{CCM}$ & 4.863 & 0.0814 & 0.101 \\
\hline $\begin{array}{l}\text { Step change in } R \text { from } 105 \Omega \text { to } \\
210 \Omega ; V_{\mathrm{g}}=21.4 \mathrm{~V}, D_{1}=0.5\end{array}$ & $\mathrm{CCM}$ & 4.855 & 0.077 & 0.106 \\
\hline $\begin{array}{l}\text { Step change in } R \text { from } 800 \Omega \text { to } \\
200 \Omega ; V_{\mathrm{g}}=21.4 \mathrm{~V}, D_{1}=0.5\end{array}$ & $\mathrm{CCM}$ & 4.818 & 0.07 & 0.088 \\
\hline $\begin{array}{l}\text { Step change in } R \text { from } 105 \Omega \text { to } \\
1,750 \Omega ; V_{\mathrm{g}}=21.4 \mathrm{~V}, D_{1}=0.5\end{array}$ & $\begin{array}{l}\text { CCM to } \\
\text { DCM }\end{array}$ & 5.872 & 0.078 & 0.0875 \\
\hline $\begin{array}{l}\text { Step change in } D_{1} \text { from } 0.3 \text { to } \\
0.5 ; V_{\mathrm{g}}=21.4 \mathrm{~V}, R=1,750 \Omega\end{array}$ & DCM & 4.761 & 0.0795 & 0.2351 \\
\hline $\begin{array}{l}\text { Step change in } D \text { from } 0.5 \text { to } \\
0.2 ; V_{\mathrm{g}}=21.4 \mathrm{~V}, R=1,750 \Omega\end{array}$ & DCM & 4.97 & 0.0815 & 0.2433 \\
\hline $\begin{array}{l}\text { Step change in } R \text { from } 1,750 \Omega \text { to } \\
2,000 \Omega ; V_{\mathrm{g}}=21.4 \mathrm{~V}, D_{1}=0.5\end{array}$ & DCM & 5.141 & 0.0396 & 0.2071 \\
\hline $\begin{array}{c}\text { Step change in } R \text { from } 1,750 \Omega \text { to } \\
105 \Omega ; V_{\mathrm{g}}=21.4 \mathrm{~V}, D_{1}=0.5\end{array}$ & $\begin{array}{l}\text { DCM to } \\
\text { CCM }\end{array}$ & 4.7313 & 0.0368 & 0.2627 \\
\hline $\begin{array}{l}\text { Step change in } V_{\mathrm{g}} \text { from } 21.4 \mathrm{~V} \text { to } \\
25 \mathrm{~V} ; R=105 \Omega ; D_{1}=0.5\end{array}$ & $\mathrm{CCM}$ & 4.7157 & 0.0672 & 0.2627 \\
\hline $\begin{array}{c}\text { Step change in } V_{\mathrm{g}} \text { from } 21.4 \mathrm{~V} \text { to } \\
25 \mathrm{~V} ; R=1,750 \Omega, D_{1}=0.2\end{array}$ & DCM & 4.9078 & 0.0436 & 0.1843 \\
\hline $\begin{array}{l}\text { Step change in } V_{\mathrm{g}} \text { from } 25 \mathrm{~V} \text { to } \\
21.4 \mathrm{~V} ; R=105 \Omega ; D_{1}=0.5\end{array}$ & $\mathrm{CCM}$ & 5.339 & 0.0628 & 0.0781 \\
\hline $\begin{array}{l}\text { Step change in } V_{\mathrm{g}} \text { from } 25 \mathrm{~V} \text { to } \\
21.4 \mathrm{~V} ; R=1,750 \Omega, D_{1}=0.2\end{array}$ & DCM & 4.604 & 0.0484 & 0.2277 \\
\hline
\end{tabular}

model with the switching model in terms of accuracy and also the experimental validation of all the models.

\subsection{Comparison of combined model and switching model}

The combined model gives all the information, as provided by the switching model. To validate this claim, the output from combined model and switching model of various converters are compared in figures 10-12. It is clear from the simulation results that the transient and steady-state values produced by the combined and switching models are similar.

\subsection{Experimental validation}

The accuracy of the models of buck, boost and buck-boost converters are verified by comparing the simulation results with that of the converter hardware. All the experiments were conducted on $20 \mathrm{~W}$ laboratory prototypes of various converters, built in lab. The switching frequency $\left(f_{\mathrm{s}}\right)$ of the firing signal to the MOSFET switch IRF741 is generated at $20 \mathrm{kHz}$ by PWM generator IC TL494. The output voltage and inductor current of various converters are recorded in the digital 
Table 17. Comparison of computation time among switching, average and combined models under transient conditions for buck-boost converter.

\begin{tabular}{|c|c|c|c|c|}
\hline Transition & Mode & $\begin{array}{l}\text { Switching } \\
\text { model (s) }\end{array}$ & $\begin{array}{l}\text { Average } \\
\text { model (s) }\end{array}$ & $\begin{array}{l}\text { Combined } \\
\text { model (s) }\end{array}$ \\
\hline $\begin{array}{l}\text { Step change in } D_{1} \text { from } 0.2 \text { to } \\
0.5 ; V_{\mathrm{g}}=20 \mathrm{~V}, R=195 \Omega\end{array}$ & $\mathrm{CCM}$ & 0.72773 & 0.01085 & 0.036695 \\
\hline $\begin{array}{l}\text { Step change in } D_{1} \text { from } 0.5 \text { to } \\
0.2 ; V_{\mathrm{g}}=20 \mathrm{~V}, R=195 \Omega\end{array}$ & $\mathrm{CCM}$ & 0.186182 & 0.012979 & 0.013756 \\
\hline $\begin{array}{l}\text { Step change in } D_{1} \text { from } 0.3 \text { to } \\
0.6 ; V_{\mathrm{g}}=20 \mathrm{~V}, R=2,000 \Omega\end{array}$ & DCM & 6.351 & 0.042876 & 0.087433 \\
\hline $\begin{array}{l}\text { Step change in } D_{1} \text { from } 0.75 \text { to } \\
0.25 ; V_{\mathrm{g}}=20 \mathrm{~V}, R=2,500 \Omega\end{array}$ & DCM & 6.4418 & 0.098904 & 0.71078 \\
\hline $\begin{array}{l}\text { Step change in } R \text { from } 150 \Omega \text { to } \\
250 \Omega ; V_{\mathrm{g}}=20 \mathrm{~V}, D_{1}=0.6\end{array}$ & CCM & 1.341 & 0.025946 & 0.029823 \\
\hline $\begin{array}{l}\text { Step change in } R \text { from } 350 \Omega \text { to } \\
150 \Omega ; V_{\mathrm{g}}=20 \mathrm{~V}, D_{1}=0.5\end{array}$ & $\mathrm{CCM}$ & 0.44658 & 0.015458 & 0.039702 \\
\hline $\begin{array}{l}\text { Step change in } R \text { from } 1,000 \Omega \text { to } \\
1,500 \Omega ; V_{\mathrm{g}}=20 \mathrm{~V}, D_{1}=0.3\end{array}$ & DCM & 3.6676 & 0.021591 & 0.024907 \\
\hline $\begin{array}{c}\text { Step change in } R \text { from } 1,750 \Omega \text { to } \\
1,250 \Omega ; V_{\mathrm{g}}=20 \mathrm{~V}, D_{1}=0.35\end{array}$ & DCM & 3.1622 & 0.027203 & 0.03116 \\
\hline $\begin{array}{l}\text { Step change in } R \text { from } 250 \Omega \text { to } \\
1,250 \Omega ; V_{\mathrm{g}}=20 \mathrm{~V}, D_{1}=0.3\end{array}$ & $\begin{array}{l}\text { CCM to } \\
\text { DCM }\end{array}$ & 13.9611 & 0.062899 & 0.096064 \\
\hline $\begin{array}{l}\text { Step change in } R \text { from } 2,500 \Omega \text { to } \\
200 \Omega ; V_{\mathrm{g}}=20 \mathrm{~V}, D_{1}=0.55\end{array}$ & $\begin{array}{l}\text { DCM to } \\
\text { CCM }\end{array}$ & 1.8534 & 0.143407 & 0.14738 \\
\hline $\begin{array}{c}\text { Step change in } V_{\mathrm{g}} \text { from } 18 \mathrm{~V} \text { to } \\
25 \mathrm{~V} ; R=150 \Omega, D_{1}=0.5\end{array}$ & $\mathrm{CCM}$ & 0.34463 & 0.018372 & 0.082372 \\
\hline $\begin{array}{l}\text { Step change in } V_{\mathrm{g}} \text { from } 18 \mathrm{~V} \text { to } \\
25 \mathrm{~V} ; R=1,500 \Omega, D_{1}=0.3\end{array}$ & DCM & 5.56905 & 0.046704 & 0.054054 \\
\hline $\begin{array}{l}\text { Step change in } V_{\mathrm{g}} \text { from } 22 \mathrm{~V} \text { to } \\
15 \mathrm{~V} ; R=2,500 \Omega, D_{1}=0.4\end{array}$ & DCM & 0.87823 & 0.011518 & 0.081345 \\
\hline
\end{tabular}

storage oscilloscope. The simulation results from switching model and experimental results are compared for validating the models. It is also clear from the previous discussions that the simulation results from combined and switching model tally with each other. Hence, it is reasonable to compare the results from switching model and experiment for verification of accuracy of the model.

The steady-state inductor current under CCM and DCM operation of the converters is compared in figures 13-18. The dynamic operation of the converters under change in duty cycle is compared in figures 19 and 20. Inductor current transient with change in duty cycle is compared in figures 21 and 22. It is clear from the results that the model is an accurate representation of the actual converter. To emphasize the accuracy of the models, the quantitative comparison of the results from switching model, combined model and experiment is provided in tables 11-13.

\section{Analysis of computational time}

The switching, average and combined models of buck, boost and buck-boost converters are simulated in MATLAB with a fixed step ODE solver. The step time for the simulation of switching, 
average and combined models of converters are $1 \mathrm{e}-7,1 \mathrm{e}-5$ and $1 \mathrm{e}-5 \mathrm{~s}$ respectively. The computational time for the converters to reach the steady-state operating condition is tabulated in table 14. The computation time of converters under transient conditions is listed in tables 15-17. From the tabulated value of computational time, it is clear that the average and combined models consume minimum time, as compared to that of switching model. During off-line simulation of dc-dc converters, the average and combined model can be satisfactorily used instead of the conventional switching model.

\section{Conclusion}

The switching, average and combined (average + harmonic) models of buck, boost and buckboost converters, including the non-idealities of the components, are developed. The models are simulated in off-line simulation environment with a fixed time-step. The time-step required for the switching model is much lower than that of the average and combined models. The computation time required by various models under steady-state and transient operating conditions of the converters are determined. From the obtained results, it is clear that the average and combined models take minimum computation time. The prototype of all the converters is built in the lab and the accuracy of the models is verified by comparing the simulation results with the hardware results. The models described in this paper are accurate and can mimic the behavior of the converters under steady-state and transient conditions. The detailed analysis of the models of the converters under various operating conditions proves that the combined model can replace the switching model of dc-dc converters, without any loss of accuracy.

\section{Acknowledgement}

This work was supported by the Department of Heavy Industry, Government of India, under the project entitled "Development of offline and real time simulators for electric vehicle/hybrid electric vehicle systems".

\section{References}

Badstuebner U, Biela J and Kolar J W 2010 Design of an 99\%-efficient, 5 kW, phase-shift PWM dc-dc converter for telecom applications. In: Twenty-Fifth Annual IEEE Applied Power Electronics Conference and Exposition, pp. 773-780

Bellur D M, Dayton O H and Kazimierczuk 2007 DC-DC converters for electric vehicle applications. In: Electrical Insulation Conference and Electrical Manufacturing Expo, pp. 286-293

Chung I, Liu W, Andrus M, Schoder K, Leng S, Cartes D A and Steurer M 2009 Integration of a bidirectional dc-dc converter model in to a large-scale system simulation of a ship board MVDC power system. In: IEEE Electric Ship Technology Symposium, pp. 318-325

Emadi A, Williamson S S and Khaligh A 2006 Power electronics intensive solutions for advanced electric, hybrid electric and fuel cell vehicular power systems. IEEE Trans. Power Electron. 21(3): 567-577

Fang C 2011 Unified discrete-time modeling of buck converter in discontinuous mode. IEEE Trans. Power Electron. 26(8): 2335-2342

Hwang T and Park S 2012 Seamless boost converter control under the critical boundary condition for a fuel cell power conditioning system. IEEE Trans. Power Electron. 27(8): 3616-3626

Jalla M M, Emadi A, Williamson G A and Fahimi B 2004 Real time state estimation of multi- converter more electric ship power systems using the generalized state space averaging method. In: $30^{\text {th }}$ Annual conference of IEEE Industrial Electronics Society, pp. 1514-1519 
Khan I A 1994 DC-to-DC converters for electric and hybrid electric vehicles. In: IEEE Proceedings of the Power Electronics in Transportation, pp. 113-122

Krein P T, Bentsman J, Bass R M and Lesieutre B C 1989 On the use of averaging for the analysis of power electronic systems. In: IEEE Power Electronics Specialists Conference, pp. 463-467

Lehman B and Bass R M 1994 Recently developed averaging theory applied to power electronic systems. In: IEEE Proceedings of the American Control Conference, pp. 1563-1567

Merdassi A, Gerbaud L and Bacha S 2008 A new automatic average modeling tool for power electronic systems. In: IEEE Power Electronics Specialists Conference, pp. 3425-3431

Mohan N, Undeland T M and Robbins W P 2007 Power electronics: Converters, applications, and design. Wiley student edition, New Delhi, India, pp. 322-341

Patil M B, Ranganathan V T and Ramanarayanan V 2009 Simulation of power electronic circuits. Narosa, New Delhi, India, pp. 17.9-17.19

Pedicini C, Iannelli L and Vasca F 2012 The averaging method for control design and stability analysis of practical switched systems. In: IEEE International Conference on Control Applications, pp. 1285-1290

Ren Y, Kang W and Qian Z 2000 A novel average model for single switch buck-boost dc-dc converter. In: Power Electronics and Motion Control Conference, pp. 436-439

Sanders S R, Noworolski J M, Liu X Z and Verghese G C 1990 Generalized averaging method for power conversion circuits. In: IEEE Proceedings of Power Electronics Specialists Conference, pp. 333-340

Saritha B, Pandey V and Narayanan G 2013 Computationally efficient model for simulation of boost converter. In: National Power Electronics Conference, IIT Kanpur, India

Vuthchhay E and Bunlaksananusorn C 2008 Dynamic modeling of a zeta converter with state- space averaging technique. In: $5^{\text {th }}$ International Conference on Electrical Engineering/Electronics, Computer, Telecommunications and Information Technology. 2: 969-972

Waffler S and Kolar J W 2009 A novel low-loss modulation strategy for high-power bidirectional buck boost converters. IEEE Trans. Power Electron. 24(6): 1589-1599

Williamson S S, Lukic S M and Emadi A 2006 Comprehensive drive train efficiency analysis of hybrid electric and fuel cell vehicles based on motor controller efficiency modeling. IEEE Trans. Power Electron. 21(3): 730-740

Zahedi B and Norum L E 2013 Modeling and simulation of all electric ships with low-voltage dc hybrid power systems. IEEE Trans. Power Electron. 28(10): 4525-4537 